JÚLIO CAMARGO DE AZEVEDO

\title{
TUTELA JURISDICIONAL ADEQUADA ÀS PESSOAS EM SITUAÇÃO DE VULNERABILIDADE
}

Dissertação de Mestrado

Orientador: Professor Rodolfo de Camargo Mancuso

Universidade de São Paulo

FACULDADE DE DIREITO

SÃo PAUlo - SP

2019 


\section{JÚLIO CAMARGO DE AZEVEDO}

\section{TUTELA JURISDICIONAL ADEQUADA ÀS PESSOAS EM SITUAÇÃO DE VULNERABILIDADE}

Dissertação de Mestrado apresentada à Banca Examinadora do Programa de Pós-Graduação em Direito da Faculdade de Direito da Universidade de São Paulo, como exigência parcial para obtenção do título de Mestre em Direito na área de concentração de Direito Processual, sob a orientação do Professor Doutor Rodolfo de Camargo Mancuso.

UNIVERSIDAde de SÃo PAUlo

FACUldade De Direito

SÃo PaUlo - SP 
Catalogação na Publicação

Serviço de Processos Técnicos da Biblioteca da

Faculdade de Direito da Universidade de São Paulo

Azevedo, Júlio Camargo de.

Tutela jurisdicional adequada às pessoas em situação de vulnerabilidade / Júlio Camargo de Azevedo. -- São Paulo, 2019. 307 p. ; $30 \mathrm{~cm}$.

Dissertação (Mestrado) - Programa de Pós-Graduação em Direito, Faculdade de Direito, Universidade de São Paulo, São Paulo, 2019.

Orientador: Rodolfo de Camargo Mancuso.

Notas de rodapé

Inclui bibliografia

1. Tutela jurisdicional. 2. Adequação procedimental. 3. Pessoas em situação de vulnerabilidade. I. Mancuso, Rodolfo de Camargo, orient. II. Título. 
Nome: AZEVEDO, Júlio Camargo de.

Título: Tutela jurisdicional adequada às pessoas em situação de vulnerabilidade

Dissertação apresentada à Faculdade de Direito da Universidade de São Paulo para a obtenção do título de Mestre em Direito.

Aprovado em:

BANCA EXAMINADORA

Presidente da Banca:

Instituição:

Julgamento:

Prof. Dr.

Instituição:

Julgamento:

Prof. Dr.

Instituição:

Julgamento:

Prof. Dr.

Instituição:

Julgamento: 
Dedico este trabalho à memória de meu pai Armando Monteiro de Azevedo, que em diversas fases da vida se viu vulnerável... 


\section{AGRADECIMENTOS}

À minha família Tânia, Ronaldo, Roberto e Vitor, pelo apoio incondicional. Um agradecimento especial à minha mãe, aquela "luzinha" sempre acesa, que gentilmente revisou o texto.

À Gabriela, pelo companheirismo e apoio demonstrado nos inúmeros momentos sacrificados à consecução desta pesquisa. Amo você.

Aos professores Ada Pellegrini Grinover, Antonio Carlos Marcato, Camilo Zufelato, Cândido Rangel Dinamarco, Fernanda Tartuce, Fernando da Fonseca Gajardoni, Marco Antonio Sabino, Maria Paula Dallari Bucci, Nelson Nery Júnior, Paulo Henrique dos Santos Lucon, Suzana Henriques da Costa, Vitor Burgo e Kazuo Watanabe pelas profícuas lições e ricos apontamentos referentes à pesquisa. Vocês contribuíram muito para a formação do processualista que pretendo ser.

À Faculdade de Direito do Largo de São Francisco, velha e sempre nova academia, pela acolhida nestes três anos de intensos estudos, amizades verdadeiras e vivências extraordinárias. Um agradecimento especial aos funcionários. Li uma vez que os anjos gostam de bibliotecas, mas só fui comprovar isso no Largo de São Francisco. Obrigado por existir Maria dos Remédios!

À Defensoria Pública paulista, por me garantir uma vida laboral com propósito. Ainda, aos colegas defensores públicos André Marcondes, Ana Paula Meirelles Lewin, Daniel Zveibel e Jairo Salvador por me auxiliarem a tornar esse sonho possível.

Aos amigos de hoje, amanhã e sempre.

Por fim, um agradecimento especial ao professor Rodolfo de Camargo Mancuso, que não ensinou pensamentos, mas a pensar, apontando um caminho sem volta pelo fascinante labirinto acadêmico. Muito mais que um orientador acadêmico, o senhor foi um orientador para a vida.

Muito obrigado a todos... 
"[...] as pessoas e os grupos sociais têm o direito a ser iguais quando a diferença os inferioriza, e o direito a ser diferentes quando a igualdade os descaracteriza”. Boaventura de Souza Santos, 2010. 


\section{RESUMO}

AZEVEDO, Júlio Camargo de. Tutela jurisdicional adequada às pessoas em situação de vulnerabilidade. 2019. 307 p. Dissertação (Mestrado em Direito Processual) - Faculdade de Direito, Universidade de São Paulo, São Paulo, 2019.

O presente trabalho tem por objetivo central discutir a viabilidade da adequação da tutela jurisdicional em favor de pessoas em situação de vulnerabilidade. Para alcance do escopo delineado a pesquisa dividiu-se em três partes. Na primeira etapa promoveu-se uma revisão bibliográfica acerca do instituto tutela jurisdicional abordando sua evolução histórica, teorias conceituais e principais classificações, sem prescindir de apontamentos referentes à importância da categoria para o estudo do processo civil contemporâneo à luz de uma perspectiva humanista. $\mathrm{Na}$ segunda etapa aprofundou-se o estudo jurídico da vulnerabilidade, evidenciando sua trajetória histórica, aportes filosóficos, conceito, espécies, classificações e fundamentos jurídicos de proteção. Na terceira etapa, investigou-se a relação entre vulnerabilidade e processo, destacando a importância de se buscar um processo civil inclusivo, participativo e não discriminatório. A seguir foram erigidas algumas balizas científicas para a adequação da tutela jurisdicional, tais como a consideração da condição vulnerável e a aplicação de vetores metodológicos, sendo exploradas hipóteses específicas de adequação, compilação que procurou sistematizar tanto técnicas processuais já previstas nas legislações protetivas, quanto hipóteses concretas de adaptação à luz do Código Processual de 2015. Por fim, cogitou-se da aplicação de um microssistema processual de proteção às vulnerabilidades.

PALAVRAS-CHAVE: Tutela jurisdicional. Adequação procedimental. Pessoas em situação de vulnerabilidade. 


\begin{abstract}
AZEVEDO, Júlio Camargo de. Appropriate judicial protection for people in vulnerable situation. 2019. 307 p. Dissertation (Master in Civil Procedure) - Faculdade de Direito, Universidade de São Paulo, São Paulo, 2019.

The main goal of this study is to discuss the viability of procedural adaptation in favor of people in vulnerable situation. In order to reach the pointed scope, the research was divided in three parts. At the first stage, it promoted a bibliographical review about the judicial protection institute, insight of its historical evolution, conceptual theories and main classifications, without regarding the importance of the category for the contemporary study of civil procedure under its humanistic perspective. On the second stage, it deepened the juridical study of vulnerability, evidencing its historical trajectory, philosophical contributions, concept, species and classifications, as well as the main legal protection basis. Finally, in the third stage, it investigated the relationship between vulnerability and civil procedure, highlighting the importance of an inclusive, participatory and non-discriminatory civil procedure. Therefore, it established some scientific basis, such as the procedural consideration about vulnerable condition and the application of methodological principles. Hereafter, it explored specific hypotheses of procedural adequacy, compilation that meant to systematize both the procedural techniques already provided in the protective legislations and the concrete adaptions under the Procedural Code of 2015. Finally, it considered the application of a procedural micro-system of vulnerability protection.
\end{abstract}

KEY WORDS: Judicial protection. Procedural adequacy. People in vulnerable situation. 


\section{SUMÁRIO}

INTRODUÇÃ

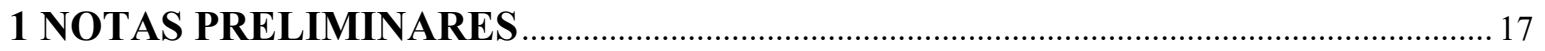

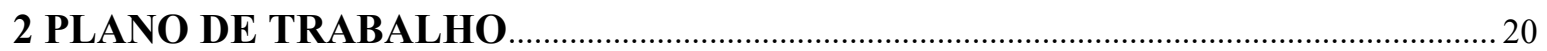

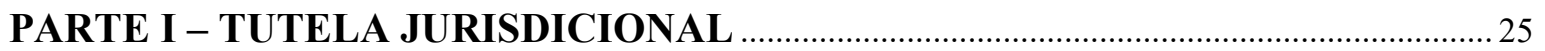

CAPÍTULO 1 - TUTELA JURISDICIONAL: EVOLUÇÃO HISTÓRICA,

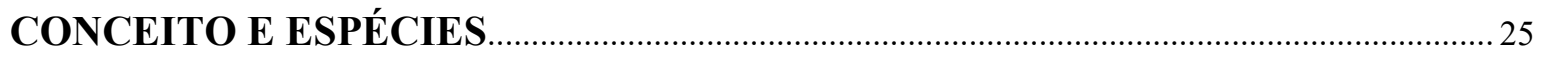

1.1 BREVES NOTAS SOBRE AS FASES METODOLÓGICAS DO PROCESSO CIVIL E A SUA INFLUÊNCIA SOBRE A NOÇÃO DE TUTELA JURISDICIONAL ...................25

1.1.1 A ruptura com a categoria da tutela jurisdicional: a passagem do sincretismo ao autonomismo processual. .25

1.1.2 A retomada científica da categoria da tutela jurisdicional: o instrumentalismo 30 1.2 A TUTELA JURISDICIONAL ENQUANTO ESPÉCIE DO GÊNERO TUTELA DOS DIREITOS 33

1.3 DELIMITAÇÃO CONCEITUAL DO DIREITO À TUTELA JURISDICIONAL .......34

1.3.1 A tutela jurisdicional enquanto resultado da atividade jurisdicional ..................34

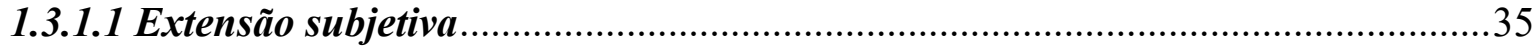

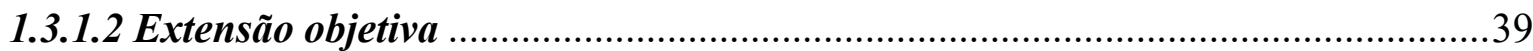

1.3.2 A tutela jurisdicional enquanto meios ordenados à consecução do resultado.....41

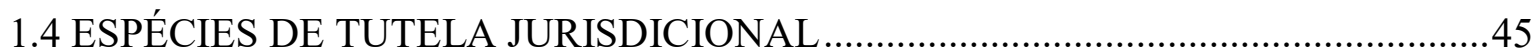

1.4.1 A tradicional classificação tripartite (tutelas cognitiva, executiva e cautelar) ....45

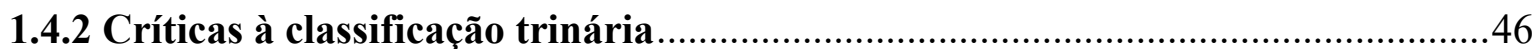

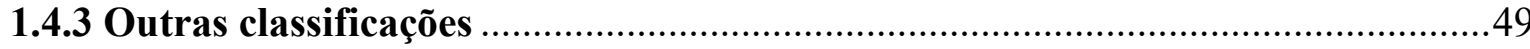

1.5 TUTELAS JURISDICIONAIS DIFERENCIADAS …...............................................

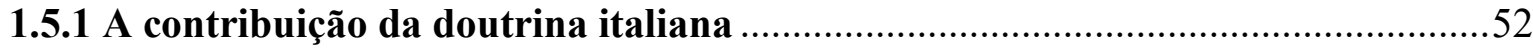

1.5.2 A tutela jurisdicional diferenciada na doutrina brasileira...................................53 
CAPÍTULO 2 - A TUTELA JURISDICIONAL NO DIREITO PROCESSO CIVIL CONTEMPORÂNEO

2.1 A CRISE DOS CLÁSSICOS INSTITUTOS FUNDAMENTAIS DO DIREITO PROCESSUAL

2.2 A TUTELA JURISDICIONAL ENQUANTO NOVO POLO METODOLÓGICO DO DIREITO PROCESSUAL CIVIL 64

2.3 O CONCEITO CONTEMPORÂNEO DE TUTELA JURISDICIONAL 66

2.4 O CONTEÚDO DO DIREITO FUNDAMENTAL À TUTELA JURISDICIONAL ... 67

2.4.1 Direito à efetividade do provimento jurisdicional 68

2.4.2 Direito à adequação do procedimento e da técnica processual 72

2.4.3 Direito à tempestividade processual 76

2.5 UMA NOVA MIRADA: A DIMENSÃO HUMANISTA DA TUTELA JURISDICIONAL 81

2.5.1 A insuficiência da noção clássica de tutela do direito material 81

2.5.2 A mudança de paradigma: da tutela de direitos à tutela das pessoas. 84

2.5.3 Um dos caminhos possíveis à tutela jurisdicional humanista: a consideração da vulnerabilidade no processo 87

PARTE II - VULNERABILIDADE. .89

CAPÍTULO 3 - VULNERABILIDADE: EXTENSÃO E COMPREENSÃO DO TERMO .89

3.1 BREVES NOTAS SOBRE A TRAJETÓRIA EVOLUTIVA DA

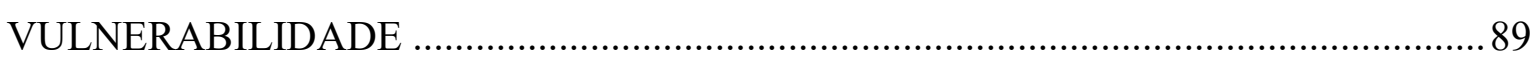

3.2 PRINCIPAIS NOÇÕES ACERCA DA VULNERABILIDADE ............................... 92

3.3 A BUSCA POR UM CONCEITO DE VULNERABILIDADE ..................................93

3.4 PREMISSAS EPISTEMOLÓGICAS AO ESTUDO JURÍDICO DA

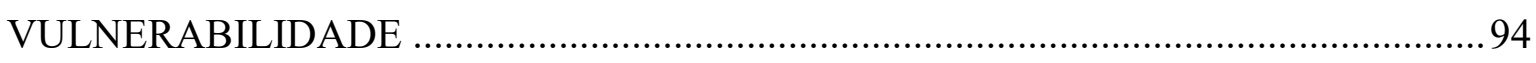

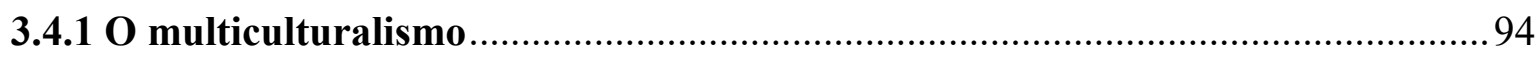

3.4.2 A insuficiência da igualdade material distributiva ......................................... 98 
3.4.3 As teorias do reconhecimento 101

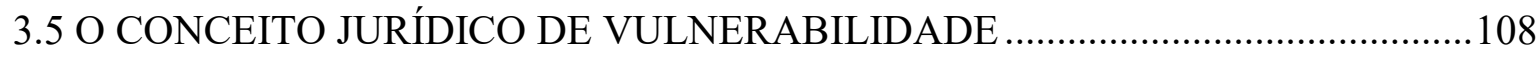

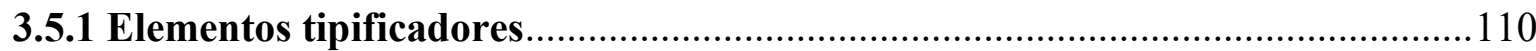

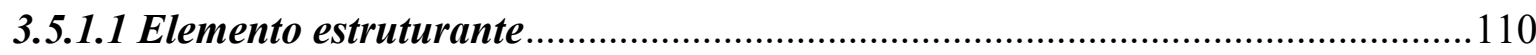

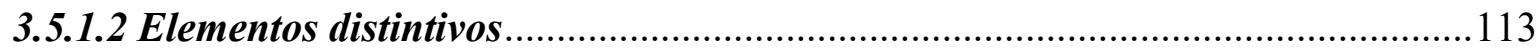

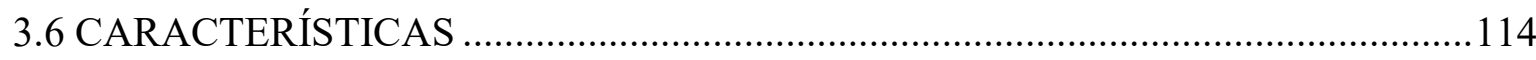

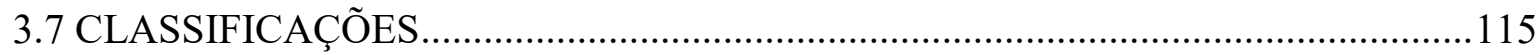

3.7.1 Por uma nova classificação: vulnerabilidade socioeconômica e vulnerabilidade

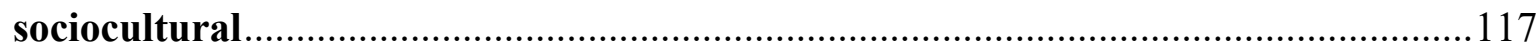

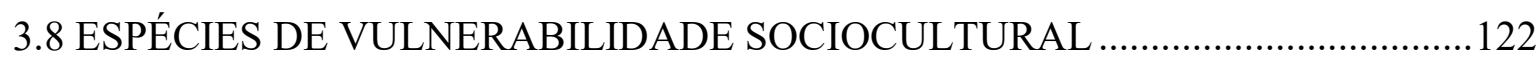

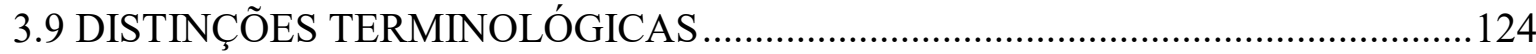

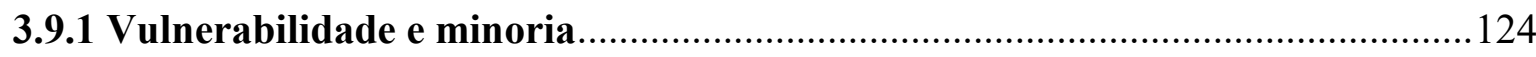

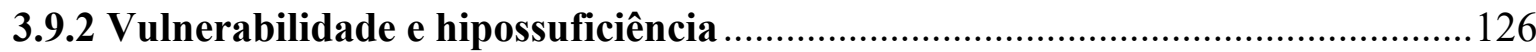

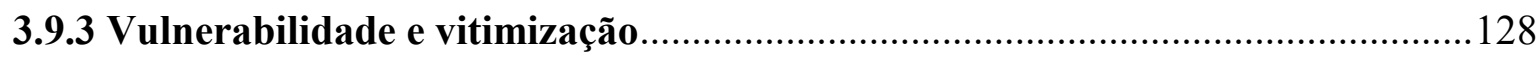

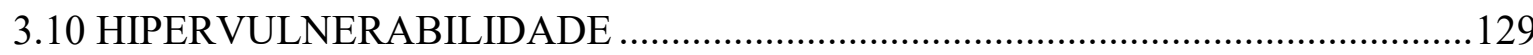

CAPÍTULO 4 - FUNDAMENTOS JURÍDICOS GERAIS DA TUTELA DA

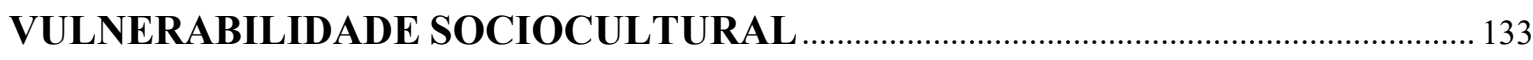

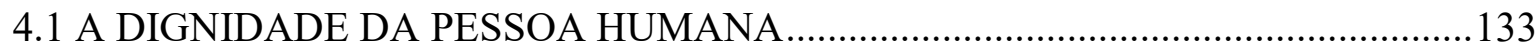

4.2 A CLÁUSULA CONSTITUCIONAL DE ANTIDISCRIMINAÇÃO .......................135

4.3 O DIREITO INTERNACIONAL DOS DIREITOS HUMANOS..............................136

4.4 AS 100 REGRAS DE BRASÍLIA SOBRE ACESSO À JUSTIÇA DAS PESSOAS EM

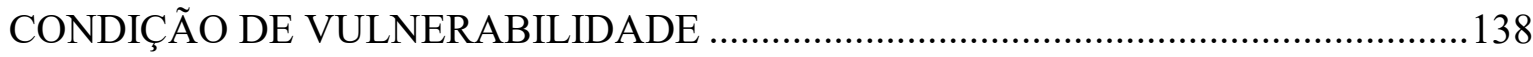

PARTE III - TUTELA JURISDICIONAL ADEQUADA ÀS PESSOAS EM SITUAÇÃO DE VULNERABILIDADE

CAPÍTULO 5 - VULNERABILIDADE E PROCESSO

5.1 COLOCANDO A PROBLEMÁTICA: A DUPLA REIVINDICAÇÃO POR JUSTIÇA CONTEMPORÂNEA E A NOÇÃO DE PROCESSO JUSTO. 
5.2.1 O processo civil no paradigma multicultural .................................................... 142

5.2.2 A insuficiência de remédios processuais redistributivos ................................... 146

5.2.3 Novas exigências normativas ao adequado acesso à justiça de pessoas em situação de vulnerabilidade. 148

5.2.3.1 A necessidade de um processo civil não discriminatório 150

5.2.3.1.1 A vedação ao hate speech processual 151

5.2.3.1.2 A vedação à emissão de críticas ou juízos morais sobre o "projeto de vida" da pessoa em condição de vulnerabilidade 154

5.2.3.2 A necessidade de um processo civil que respeite à diferença 155

5.2.3.3 A necessidade de um processo civil inclusivo 156

5.2.3.3.1 Das medidas administrativas de facilitação ao acesso à justiça 157

5.2.3.3.2 Das medidas de adaptação procedimental 158

5.2.3.4 A necessidade de um processo civil que valorize a autonomia individual, a liberdade de escolha e a participação de sujeitos vulneráveis 160

5.3 INSTRUMENTOS DE TRATAMENTO DA VULNERABILIDADE NO PROCESSO: AS “AÇÕES AFIRMATIVAS PROCESSUAIS” 163

CAPÍTULO 6 - TUTELA JURISDICIONAL ADEQUADA Às PESSOAS EM SITUAÇÃO DE VULNERABILIDADE SOCIOCULTURAL 165

6.1 DELIMITAÇÃO DA ANÁLISE 165

6.1.1 O primeiro recorte proposto: a dimensão da adequação da tutela jurisdicional 165

6.1.2 O segundo recorte proposto: a vulnerabilidade sociocultural 165

6.2 PREMISSAS CIENTÍFICAS GERAIS 166

6.2.1 A tutela jurisdicional humanista como condição de possibilidade para um processo civil inclusivo. 166

6.3.2 Fundamentos normativos 167

6.2.3 Espécies de adequação da tutela jurisdicional em favor de grupos vulneráveis 
6.2.4 Pressuposto à adequação: a identificação da condição vulnerável. 169

6.2.5 Princípios metodológicos 172

6.2.5.1 Princípio "pro persona" ou "pro homine" 173

6.2.5.2 Princípio "favor vulnerabilis" 174

6.2.5.3 Princípio da adaptação razoável ou da acomodação razoável 175

6.2.5.4 Princípio "in dubio pro vulnerabilis" 176

6.2.5.5 Princípio da proteção integral 177

6.2.5.6 Princípio da não fruição obrigatória da ação afirmativa 178

6.3 SISTEMATIZAÇÃO DAS PRINCIPAIS TÉCNICAS PROCESSUAIS APLICÁVEIS 178

6.3.1 Normas processuais fundamentais 179

6.3.1.1 A boa-fé processual e a vedação ao "hate speech" no processo 179

6.3.1.2 A cooperação como valorização da autonomia e garantia de informação 180

6.3.1.3 Contraditório como garantia de participação-influência 182

6.3.2 Métodos consensuais de resolução de conflitos 184

6.3.2.1 Viabilidade da resolução consensual de conflitos envolvendo sujeitos vulneráveis 186

6.3.2.2 Adequação do procedimento consensual 187

6.3.3 Competência 189

6.3.3.1 A especialização da competência 189

6.3.3.2 $O$ "forum shopping” (escolha do foro mais favorável) e a flexibilização das regras de modificação da competência territorial

6.3.4 Representação processual e assistência jurídica 196

6.3.4.1 A dispensa da capacidade postulatória em favor da parte vulnerável 196

6.3.4.2 A Defensoria Pública como garantia de integralidade e gratuidade da assistência jurídica. .198

6.3.5 Curadoria especial e a intervenção do custos iuris .200

6.3.5.1 A curadoria especial em favor do incapaz sem representante legal ou com interesses colidentes 201

6.3.5.2 A curadoria especial em favor do deficiente intelectual .202 
6.3.5.3 A intervenção do Ministério Público enquanto “custos iuris" 204

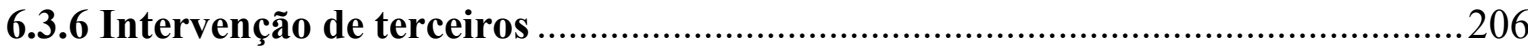

6.3.6.1 Intervenções de terceiro em favor da pessoa vulnerável ....................................206

6.3.6.2 A hipótese do artigo 206 do Estatuto da Criança e do Adolescente .....................208

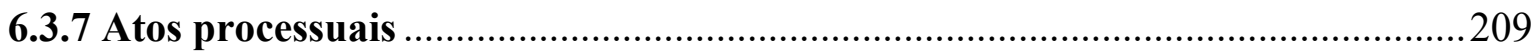

6.3.7.1 Adequações pertinentes à forma e ao lugar dos atos processuais ......................209

6.3.7.1.1 Prioridade de tramitação em favor de sujeitos vulneráveis ...............................209

6.3.7.1.2 Ampliação das hipóteses de segredo de justiça ...................................................2 214

6.3.7.1.3 Concentração de atos processuais e a valorização da oralidade ..........................215

6.3.7.1.4 Processamento nas férias forenses e prática de atos em horários noturnos ........216

6.3.7.1.5 Realização de atos jurisdicionais no lugar indicado pela pessoa vulnerável ......217

6.3.7.2 Adequações pertinentes à comunicação dos atos processuais ..........................2218

6.3.7.2.1 Exceção à regra da citação epistolar ..................................................................218

6.3.7.2.2 Utilização de meios eletrônicos em favor da parte vulnerável ............................219

6.3.7.3 Adequações pertinentes aos prazos processuais .................................................220

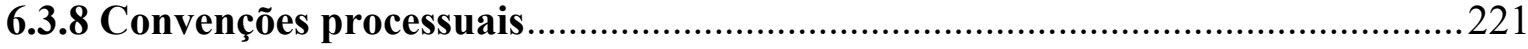

6.3.8.1 Limites à autonomia privada pela vulnerabilidade da parte ..............................223

6.3.8.2 A possibilidade de sujeitos vulneráveis firmarem convenções processuais ........225

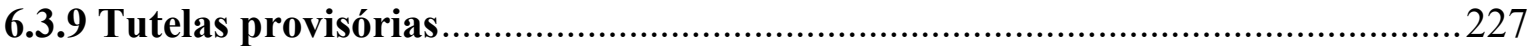

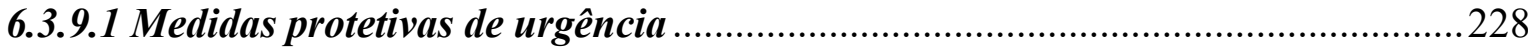

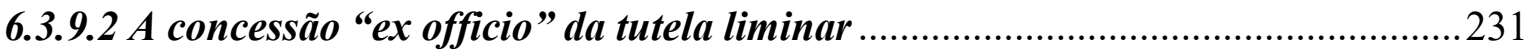

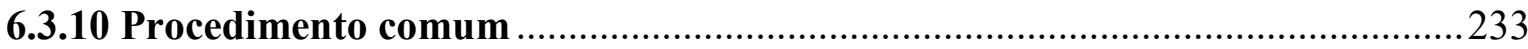

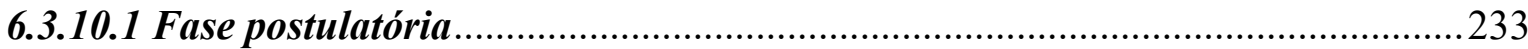

6.3.10.1.1 Adaptações pertinentes aos requisitos da petição inicial ...................................233

6.3.10.1.2 Adaptações pertinentes ao exercício do direito de defesa ..............................235

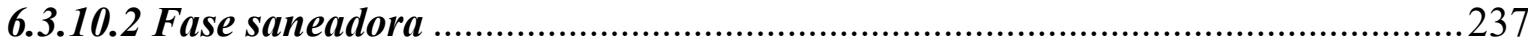

6.3.10.2.1 A atuação de equipes de apoio multidisciplinar .............................................238

6.3.10.2.2 A convocação de órgãos responsáveis pela assistência social...........................239

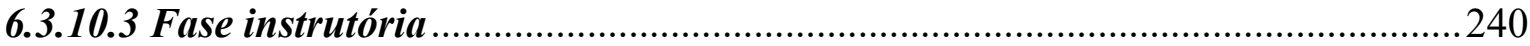

6.3.10.3.1 A distribuição do ônus da prova in favor vulnerabilis......................................240 
6.3.10.3.2 A ação probatória autônoma como garantia de não revitimização .243

6.3.10.4 Fase decisória e recursal .244

6.3.10.4.1 A rescindibilidade da sentença interna contrária à decisão erga omnes da Corte Interamericana de Direitos Humanos. .244

6.3.10.4.2 O controle de convencionalidade via recursos excepcionais .246

6.3.10.4.3 Especificidades recursais em favor da criança e do adolescente .248

6.3.10.5 Fase executiva .249

6.3.10.5.1 A aplicação de medidas executivas atípicas na tutela do crédito de indivíduos vulneráveis .249

6.3.10.5.2 A dispensa de caução para levantamento de depósito e para a concessão de efeito suspensivo aos embargos à execução. .252

6.3.11 Procedimentos especiais .254

6.3.11.1 Inadequação do procedimento especial de "interdição" em relação à pessoa com deficiência. .256

6.3.11.2 A facultatividade da sessão consensual no procedimento especial de família em caso de vulnerabilidade. .259

6.3.12 Sistemática de precedentes judiciais e litígios repetitivos .260

6.3.12.1 A técnica da distinção ("distinguishing”) como garantia do direito à diferença .262

6.3.12.2 A técnica da superação (“overruling”) como garantia de revisão de precedentes contrários aos direitos humanos de grupos vulneráveis. .264

6.3.12.3 A participação de grupos vulneráveis na formação dos precedentes judiciais. 265 6.4 UMA PROPOSTA FINAL: O MICROSSISTEMA PROCESSUAL DE PROTEÇÃO ÀS VULNERABILIDADES .268 


\section{INTRODUÇÃO}

\section{NOTAS PRELIMINARES}

Há algum tempo, os estudiosos do processo vêm se preocupando com o tema da adequação da tutela jurisdicional. Fala-se, inclusive, em um "direito ao procedimento adequado", na feliz expressão de Dinamarco. Afirma-se, nesse sentido, que a técnica processual deve abrir caminho à adequada tutela dos direitos, permitindo que situações carentes de chancela encontrem efetiva salvaguarda na garantia constitucional de acesso à justiça (art. $5^{\circ}$, inc. $\mathrm{XXXV}, \mathrm{CF} / 88)$.

Mas isso nem sempre foi assim. Por tentar afastar o processo de sua tradição privatista, a fase autonomista baniu o tema da tutela dos direitos dos estudos de Direito Processual, primando pela independência dos institutos processuais em relação às categorias de direito material. A retomada do tema à processualística moderna somente adveio por intermédio da visão instrumentalista do processo, corrente metodológica que colocou em destaque os resultados almejados sob o prisma da efetividade.

Se é certo, entretanto, que a fase instrumentalista foi responsável pelo resgate científico da tutela dos direitos no plano processual, parece igualmente correto afirmar que o instrumentalismo enquanto metodologia não esgota ou resume o estudo contemporâneo da tutela jurisdicional. Sob o prisma do processo civil constitucional, o tema vem assumindo um papel científico cada vez mais destacado, polo metodológico em torno do qual orbitam estudos acerca de outros institutos processuais e sua disciplina.

Com efeito, quando vista em uma perspectiva bifocal, a tutela jurisdicional pode ser pensada tanto pelo prisma dos resultados da atividade judicante, isto é, a partir dos aspectos práticos e jurídicos que a jurisdição exerce sobre o plano do direito material e sobre a vida das pessoas, quanto pelo prisma dos meios preordenados à consecução dos objetivos almejados, englobando aqui a dimensão do procedimento, da técnica processual, das garantias processuais e das formas executivas.

Já no que toca ao seu conteúdo, a tutela jurisdicional vem sintetizando a aquilo que a doutrina ocidental convencionou denominar de processo justo (giusto processo; fair procedure; faires Verfahren), agregando os direitos à efetividade, à adequação da técnica processual e à razoável duração do processo. Daí porque possível, hodiernamente, cogitar de 
uma tutela jurisdicional adequada, eis que adequar significa pressupor um nexo de finalidade entre o direito material afirmado e o instrumento processual utilizado para o alcance dos resultados úteis perseguidos.

Ocorre, porém - e aqui reside o ponto alto da pesquisa que se pretende -, que a adequação da tutela jurisdicional no Estado Constitucional não pode se adstringir unicamente às necessidades abstratas do direito material. No paradigma constitucional do processo, o instituto deve centrar-se na proteção da pessoa, na garantia dos direitos fundamentais e na promoção dos direitos humanos, levando também em consideração as dificuldades concretas enfrentadas pelos cidadãos que buscam o acesso ao Poder Judiciário.

Crível projetar, desse modo, uma reorientação funcional acerca da categoria da tutela jurisdicional no processo civil contemporâneo, a qual deve considerar não apenas a tutela dos direitos, mas também - e precipuamente - a tutela das pessoas. Muda-se, nesta perspectiva, o foco do processualista: da tutela do ordenamento jurídico abstrato para a tutela de pessoas de carne e osso. Plausível repensar, ademais, a técnica processual e o procedimento a partir das fragilidades evidenciadas pelos sujeitos processuais sob o crivo do contraditório. Um dos caminhos possíveis para este chamado humanitário à tutela jurisdicional decorre da consideração da vulnerabilidade no processo.

O instituto, que não é novo, fazendo-se presente nas discussões humanas desde a Grécia Antiga, evoluiu de uma noção meramente biológica de fragilidade ("todo ser humano é vulnerável") para alcançar uma noção contemporânea de risco social, transformando-se em dispositivo funcional relevante a indicar os processos de exclusão e as assimetrias de poder a que estão submetidos grupos sociais marginalizados.

Não só. A interdisciplinariedade vivenciada pela vulnerabilidade em tempos pósmodernos agrega a esta categoria um poderoso potencial prospectivo, orientador de um agir voltado à superação dessas condições de fragilidade. Desse modo, a vulnerabilidade deve ser encarada como ferramenta analítica vigorosa nos dias atuais, razão de sua ampla difusão nos mais diversos ramos do saber.

Cotejando as ideias até aqui apresentadas, isto é, a concepção humanista da tutela jurisdicional e a noção contemporânea de vulnerabilidade, entende-se possível raciocinar a adequação da tutela jurisdicional a partir das situações de vulnerabilidade de indivíduos e grupos marginalizados no contexto nacional, calibrando o procedimento à luz das fragilidades sociais evidenciadas sob o crivo do contraditório.

Essa mudança de postura, todavia, abriga cristalinos desafios. De saída, aponta-se a dificuldade de se trabalhar a temática da vulnerabilidade sob o prisma do Direito, conceito 
interdisciplinar que pode tanto tangenciar a fragilidade de ordem biológica, inerente a todos os seres humanos, quanto a fragilidade de ordem sociocultural, derivada de relações de subordinação e assimetrias de poder que favorecem um exercício desigual de cidadania.

No plano jurídico brasileiro, aliás, comumente o termo se associa a uma noção dogmática do Direito do Consumidor, fruto de sua expressa previsão no artigo $4^{\circ}$, inciso I, da Lei $\mathrm{n}^{\mathrm{o}}$ 8.072/1990. Referida vinculação à proteção das relações comerciais modernas, entretanto, nem sempre se coaduna com os pressupostos jusfilosóficos por que se pautam os direitos humanos, restringindo a dimensão conceitual da vulnerabilidade ao arquétipo legal instituído por normas destinadas a regular uma sociedade de consumo.

Ademais, em que pese a popularização da expressão, grassa intensa insegurança jurídica sobre o manejo técnico da vulnerabilidade enquanto ferramenta epistemológica, fator que dificulta a abordagem jurídica voltada à compreensão do instituto, empobrecendo sua disposição heurística para a remoção de obstáculos procedimentais frente à garantia de acesso à justiça. Daí já se extrai a importância do presente trabalho, uma vez que a utilização da vulnerabilidade não deve se transformar em categoria científica de utilização utilitária ou intuitiva, favorecendo uma fragilização epistêmica.

Outro fator de complicação refere-se à vasta miscelânea de grupos vulneráveis existentes na gramática social brasileira - ex: pessoas com deficiência, mulheres, idosos, crianças e adolescentes, afrodescendentes, quilombolas, indígenas, população LGBTI, refugiados, imigrantes e deslocados internos, pessoas em situação de rua etc. - fato este que, conjugado ao amplo arcabouço legislativo nacional e supranacional relativo às vulnerabilidades, dificulta a adequada identificação da parte vulnerável perante o Sistema de Justiça, assim como a adoção de medidas, apoios ou remédios jurídicos em favor desses sujeitos.

Por fim, o caldo cultural em que jaz o processo civil atual, caracterizado pela tutela prioritária das relações patrimoniais, mercantis e fiscais, pelo alcance de índices massivos de produtividade e, mais recentemente, pelo tratamento da litigiosidade serial mediante a replicação de padrões decisórios, contribui para embaçar as lentes do processualista, impedindo-o muitas vezes de enxergar o processo enquanto instrumento democrático de tutela da diversidade e garantia de inclusão social de segmentos marginalizados. Some-se a tudo isso a baixa formação humanística dos profissionais que integram as instituições do Sistema de Justiça brasileiro, os quais, especialistas no saber dogmático, raramente conseguem oportunizar uma adequada identificação da vulnerabilidade no processo, carecendo, ademais, de um olhar sensibilizado em torno da dura realidade experimentada pela população excluída. 
A propósito, há muito se fala em adequação judicial do procedimento, mas olvidase que a formação jurídica do profissional brasileiro é essencialmente generalista, dedutiva e dogmática, o que inviabiliza, na maioria das vezes, a adoção de medidas particulares, indutivas ou pragmáticas, transformando a exigência de adequação da tutela jurisdicional em verdadeiro mise en scène metodológico.

Movido por estes desafios, mesmo assumindo os perigos de uma análise embrionária, esta pesquisa pretende se debruçar sobre o problema geral da adequação da tutela jurisdicional em favor das pessoas em situação de vulnerabilidade, procurando compilar, de um lado, as técnicas processuais já previstas nas legislações protetivas, facilitando assim o caminho do jurista envolto neste vasto mar legislativo, sem prescindir de evidenciar, de outro, hipóteses concretas de adaptação das técnicas processuais inseridas no Código Processual de 2015, evitando que a adequação da tutela jurisdicional permaneça restrita às muradas da academia. A proposta é fornecer um substrato acadêmico que transite entre a teoria e a prática, servindo à emancipação dogmática de práticas jurídicas futuras.

Para tanto, importante afiançar o plano de trabalho projetado.

\section{PLANO DE TRABALHO}

Na etapa inicial da pesquisa, optou-se por uma revisão bibliográfica da categoria da tutela jurisdicional, investigando sua evolução histórica, delimitação conceitual, espécies e principais classificações existentes no Direito Processual Civil brasileiro, sem prescindir de breves menções à temática das tutelas jurisdicionais diferenciadas, levando em consideração a influência exercida pelo processo civil italiano. Doutro giro, deixou-se de analisar perspectivas da tutela jurisdicional relacionada a outros ramos do Direito nacional, como, verbi gratia, a tutela jurisdicional penal, a tutela jurisdicional trabalhista, a tutela jurisdicional eleitoral etc.

No segundo capítulo, buscou-se assentar o estado d'arte que a categoria galga no cenário processual hodierno, eixo metodológico em torno do qual orbita a explicação de outros institutos processuais, sintetizando a noção de processo justo (tutela jurisdicional efetiva, adequada e tempestiva). Doravante, apresentou-se a chamada tutela jurisdicional humanista, visão que realça a tutela das pessoas como finalidade precípua do processo civil contemporâneo.

Na segunda etapa da pesquisa, investiu-se inicialmente em uma apresentação geral da categoria da vulnerabilidade, evitando que sua natureza interdisciplinar ofuscasse a adequada compreensão e extensão do termo, fragilizando sua real utilidade jurídica. Partindo deste 
objetivo geral, alguns objetivos específicos foram predeterminados. Ei-los: i) apresentar a trajetória evolutiva e as principais noções conceituais de vulnerabilidade; ii) evidenciar os aportes filosóficos para o estudo jurídico da vulnerabilidade (multiculturalismo, insuficiência da igualdade material distributiva e apresentação das teorias do reconhecimento); iii) delimitar um conceito jurídico de vulnerabilidade, apresentando seus elementos estruturante e distintivos; iv) elucidar as principais características, classificações, espécies e distinções terminológicas referentes à categoria, abordando, ao final, o fenômeno da hipervulnerabilidade.

No segundo capítulo foram apresentados os fundamentos jurídicos que oferecem supedâneo à tutela jurídica da vulnerabilidade no contexto nacional, abordando-se a dignidade da pessoa humana, a cláusula constitucional de antidiscriminação, os tratados e convenções internacionais de direitos humanos, além das 100 Regras de Brasília sobre Acesso à Justiça das Pessoas em Condição de Vulnerabilidade.

$\mathrm{Na}$ terceira e última etapa, objetivou-se investigar a complexa relação entre vulnerabilidade e processo, evidenciando-se a problemática da dupla reivindicação por justiça contemporânea (redistribuição e reconhecimento) a partir da noção de processo justo. Por conseguinte, valendo-se das premissas jusfilosóficas soerguidas para o tratamento jurídico da vulnerabilidade, discutiu-se o lugar do processo civil no paradigma multicultural, a insuficiência dos remédios processuais redistributivos, além das novas exigências normativas impostas pelo reconhecimento da diversidade de indivíduos e grupos vulneráveis.

A partir destas linhas mestras, novos objetivos específicos foram delineados: i) demonstrar a importância de um processo civil não discriminatório, que combata o hate speech processual e a emissão de críticas ou juízos morais sobre o "modo de ser" ou sobre o "projeto de vida" da pessoa em condição de vulnerabilidade; ii) evidenciar a importância do respeito à diferença no processo, permitindo a adequada identificação da vulnerabilidade e o combate à anulação processual da diferença; iii) ressaltar a necessidade de um processo civil inclusivo, que invista em medidas administrativas de facilitação ao acesso à justiça e em técnicas processuais adaptadas às situações de vulnerabilidade presentes nos foros; iv) destacar a relevância da valorização da autonomia individual, da liberdade de escolha e da participação de sujeitos vulneráveis nos processos a eles concernentes, evitando-se uma adequação processual paternalista ou assistencialista. No quinto capítulo, optou-se por explorar os instrumentos de tratamento da vulnerabilidade no processo, ações afirmativas processuais que foram especificadas à luz da classificação operada no segundo capítulo (socioeconômicas e socioculturais). 
Por derradeiro, o sexto capítulo foi responsável por estabelecer a delimitação de análise, recorte temático que se demonstra importante tanto pelos caminhos que abrem quanto pelas restrições reveladas. Dois foram os recortes assumidos: a dimensão da adequação da tutela jurisdicional e a análise da vulnerabilidade sociocultural.

À luz do primeiro recorte, objetivou-se compilar tanto as ações afirmativas processuais estabelecidas em face de indivíduos vulneráveis pelo ordenamento jurídico brasileiro, quanto as possíveis hipóteses concretas de adaptação do procedimento e das técnicas processuais inseridas no Código Processual de 2015. Como estruturação, optou-se pela sistematização embasada nos grandes temas de Direito Processual Civil, a partir da topografia adotada pela Codificação de 2015. Passou-se, assim, pelas normas fundamentais do processo, métodos consensuais de resolução de conflitos, competência, representação processual e assistência jurídica, intervenção de terceiros, forma dos atos processuais, convenções processuais, tutelas provisórias, fases do procedimento comum (postulatória, saneadora, instrutória, decisória, recursal e executiva), procedimentos especiais, até alcançar a sistemática dos precedentes e o tratamento da litigância repetitiva. Adotou-se como método de análise a perspectiva dogmática.

Doutro giro, deixou-se de investigar critérios relacionados à efetividade ou à tempestividade processual, tais como fatores de eficiência, de infraestrutura judiciária, de gerenciamento de casos, assim como coeficientes de letargia do processo e avaliações de desempenho por critérios quantitativos. Ademais, muito embora grande parte das técnicas analisadas também ostentem aplicabilidade perante a seara do processo coletivo, este trabalho optou por não se debruçar sobre as especificidades procedimentais relacionadas à tutela dos direitos transindividuais de grupos vulneráveis, centrando-se na tutela individual e na Codificação de 2015.

Já como segundo recorte proposto, a avaliação recaiu sobre as hipóteses de vulnerabilidade sociocultural, isto é, fragilidades sociais ligadas à diversidade culturalidentitária de grupos historicamente discriminados. A delimitação empreendida dialoga, portanto, com a classificação introduzida na segunda parte desta pesquisa (vulnerabilidade socioeconômica e vulnerabilidade sociocultural), objetivando alcançar pessoas com deficiência, mulheres, idosos, crianças e adolescentes, afrodescendentes, quilombolas, indígenas, população LGBTI, refugiados, imigrantes e deslocados internos e, mais restritamente, pessoas em situação de rua.

Não foram avaliadas, de outra banda, identidades socioculturais menos presentes na realidade forense brasileira, tais como os ciganos, os grupos faxinais, as comunidades 
ribeirinhas, as quebradeiras de coco babaçu, as vazanteiras, as geraizeiras, os seringueiros, as catingueiras, os castanheiros, o que não impede sejam estes grupos abarcados pelos instrumentos protetivos aqui elencados, especialmente à luz da proposta de intercomunicação das regras protetivas.

O trabalho também deixar de abordar situações envolvendo vulnerabilidades socioeconômicas, aqui compreendidos os enfermos, os hipossuficientes econômicos, os trabalhadores, os analfabetos, os sem-moradia, os sem-terra, além dos consumidores. Embora de suma relevância para a reversão dos quadros de desigualdade no país, considerou-se que tais grupos já contam com bibliografia considerável no Direito Processual brasileiro. Por tais razões, optou-se por conferir enfoque específico às hipóteses de vulnerabilidade sociocultural e ao tratamento processual de indivíduos e grupos historicamente discriminados.

Compreende-se que o recorte proposto atende a uma perspectiva funcional e pragmática relacionada à Ciência Processual, orientando a sistematização e a aplicação pragmática de remédios processuais inclusivos, além de evitar o indesejado tratamento das vulnerabilidades identitárias pela via única dos remédios redistributivos.

Sobreleva referir, por fim, em termos de delimitação de análise, que este estudo não pretende esgotar todas as hipóteses de adequação da técnica processual relacionadas a cada um dos grupos vulneráveis aqui suscitados, tarefa invencível que não contribuiria para a extração de um fio de racionalidade comum envolvendo a tutela jurisdicional destes indivíduos. A proposta, ao invés, é compilar os principais remédios afirmativos que se relacionam à tutela jurisdicional de grupos identitários marginalizados, projetando uma aplicação sistemática das técnicas desvendadas em favor de milhares de cidadãos vulneráveis que batem cotidianamente às portas do Poder Judiciário em busca de acesso (adequado) à Justiça.

Acima de tudo, que este seja um trabalho útil para o cotidiano dos foros. É o que humildemente se deseja. 


\section{NOTAS CONCLUSIVAS}

1. A passagem da fase privatista para a fase autonomista foi determinando para o banimento do tema da tutela jurisdicional dos estudos de Direito Processual, ruptura influenciada pelo afastamento científico do processo em relação ao direito material. A retomada do tema à processualística moderna somente se desenvolve a partir do instrumentalismo, fase metodológica que favoreceu o estudo do direito processual à luz do direito material, resgatando a tutela jurisdicional enquanto categoria científica e objeto de análise do processo civil contemporâneo.

2. Conceitualmente, a tutela jurisdicional consubstancia espécie de tutela jurídica tout court, referindo-se ao amparo que, por obra da jurisdição, o Estado presta às pessoas e aos direitos materiais via processo em contraditório. Trata-se de direito fundamental que pode ser pensado tanto pelo prisma do resultado da atividade jurisdicional, isto é, a partir dos aspectos práticos e jurídicos que a decisão exerce sobre o direito material e sobre a vida das pessoas, quanto pelo prisma dos meios preordenados à consecução dos resultados prometidos, englobando o procedimento, a técnica processual e as formas executivas.

3. Em sua extensão subjetiva, a tutela jurisdicional alcança indistintamente tanto ao autor quanto ao réu. Nesta ótica, a experiência jurisdicional da tutela do direito agrega não apenas a preservação de direitos materiais, mas também a preservação de direitos e garantias processuais, como o devido processo legal, o contraditório e a ampla defesa. Não há, igualmente, diferença qualitativa entre a tutela jurisdicional prestada ao autor e aquela dirigida ao réu, a qual se diferencia apenas em razão da intensidade do amparo jurídico dirigido ao vencedor. Já em sua extensão objetiva, a tutela jurisdicional abrange não apenas a tutela do ordenamento objetivo, mas também - e precipuamente - a tutela das pessoas. Tal se verifica, especialmente, quando a atividade jurisdicional recai sobre pretensões que demandam proteção ao patrimônio existencial dos sujeitos processuais.

4. No que tange a seu conteúdo, o direito fundamental à tutela jurisdicional sintetiza o chamado processo justo (giusto processo; fair procedure; faires Verfahren), orientando-se por três dimensões definidas pela doutrina contemporânea: i) direito à efetividade do provimento jurisdicional; ii) direito à adequação do procedimento e da técnica processual; iii) direito à 
tempestividade. Todas estas dimensões concorrem para a garantia do direito fundamental à tutela jurisdicional.

5. O paradigma constitucional do processo impõe uma reorientação funcional do clássico conceito de tutela jurisdicional, migrando da ideia de tutela de direitos subjetivos abstratos para a ideia de tutela das pessoas. A tutela jurisdicional humanista, portanto, é aquela que coloca em realce os compromissos políticos e sociais do Direito Processual Civil em relação à proteção da dignidade do homem e à promoção dos direitos humanos (artigos $1^{\circ}, 8^{\circ}$ e 13 do Código Processual de 2015).

6. Sob o prisma da adequação, a adoção de uma tutela jurisdicional humanista implica pensar a predisposição da técnica processual levando-se em consideração as necessidades concretas das pessoas que acessam o Poder Judiciário em situação de fragilidade. Cumpre, portanto, à técnica processual a missão constitucional de ofertar meios operacionais para que a tutela jurisdicional não implique fator de injustiça procedimental às partes.

7. À luz dos compromissos políticos e sociais assumidos pelo Estado Constitucional brasileiro, a adequação da técnica processual não pode deixar de considerar a vulnerabilidade dos sujeitos processuais que acessam a justiça na defesa de seus direitos, resguardando, de um lado, sua dignidade, igualdade e diversidade, e combatendo, de outro, a discriminação, a exclusão e a estigmatização, elementos que obstaculizam o acesso à ordem jurídica justa.

8. Embora compreenda uma ferramenta interdisciplinar vigorosa em tempos atuais, quando pensada pelo prisma do Direito a vulnerabilidade deve evitar uma aproximação com a vulnerabilidade natural (inerente a todo ser humano). Deve, ao invés, ser pensada sob uma ótica deontológica, capaz de orientar ações voltadas ao adequado tratamento de situações de risco social, servindo de princípio progressivo à superação de condições de fragilidade.

9. São consideradas premissas epistemológicas ao estudo jurídico da vulnerabilidade, o multiculturalismo, a insuficiência da igualdade material distributiva e as teorias sobre o reconhecimento. Possível concluir, portanto, que: i) a questão da vulnerabilidade de indivíduos e grupos encontra-se hoje inserida no paradigma multicultural da sociedade globalizada; ii) o princípio da igualdade substantiva, instrumentalizado por meio de remédios redistributivos de bens e recursos, é insuficiente ao adequado tratamento de muitas reivindicações 
contemporâneas por justiça, as quais almejam não apenas redistribuição, mas também reconhecimento; iii) face à importância do reconhecimento da diferença para uma existência digna, necessário investir em medidas inclusivas que permitam a valorização da diversidade, o enfrentamento de injustiças culturais e a eliminação de padrões discriminatórios envolvendo grupos marginalizados.

10. Juridicamente, a vulnerabilidade pode ser conceituada como a situação de predisposição a um risco social, ostentada por um sujeito ou grupo, a qual, em função de determinantes históricas, sociais e culturais, favorece uma condição específica de violação de direitos humanos, reprodutora de situações de desrespeito, subjugação, assimetria de poder ou diminuição da cidadania, ofendendo a existência digna.

11. São elementos tipificadores da vulnerabilidade o elemento estruturante e os elementos distintivos. O elemento estruturante revela-se na condição vulnerável, a qual, por sua vez, reúne as noções de risco social e violação de direitos humanos. Já os elementos distintivos congregam qualificativos da vulnerabilidade na gramática social contemporânea, podendo se manifestar em razão da idade, do gênero, da raça, da etnia, do estado físico ou mental, da situação socioeconômica, dentre outras experiências sociais.

12. São características da vulnerabilidade a construtividade, a reversibilidade, a transitividade e a interseccionalidade. A primeira indica que a vulnerabilidade deve ser considerada como um constructo, originado de fatores históricos, sociais e políticos reproduzidos ao longo do tempo. A segunda aponta que a vulnerabilidade apresenta uma descontinuidade viável à luz de práticas sociais que amenizam o processo de marginalização. A terceira informa que a vulnerabilidade é mutável no tempo, sendo dinamicamente moldada por relações sociais. Por fim, a quarta indica que as diferentes manifestações da vulnerabilidade sofrem influência recíproca na interação social.

13. À luz da dualidade de reivindicações por justiça na contemporaneidade (redistribuição e reconhecimento), possível classificar a vulnerabilidade em socioeconômica e sociocultural. No primeiro caso, vincular-se-ia à desigual distribuição de bens e recursos sociais, demandando medidas redistributivas para seu adequado tratamento, à luz do princípio da isonomia. No segundo caso, imbricar-se-ia às reivindicações de ordem cultural, histórica ou identitária, cujas aspirações por reconhecimento reclamam medidas inclusivas à luz da do respeito à diferença. 
Assim, enquanto a igualdade se opõe à desigualdade revelada pela injusta distribuição de bens e recursos sociais, a diferença se opõe à padronização social e ao arquétipo homogêneo, combatendo a desintegração social derivada do não reconhecimento de identidades.

14. Formam espécies socioculturais de vulnerabilidade a etária, a biopsíquica, a étnica-racial e a de gênero. No primeiro grupo encontram-se crianças, adolescentes, jovens e idosos. No segundo, as comunidades tradicionais (índios, quilombolas, etc.), minorias étnicas (migrantes, refugiados etc.) além de discriminados raciais (caso dos negros). No terceiro, situam-se as pessoas com deficiência (física, intelectual ou sensorial). Já a vulnerabilidade de gênero reúne fragilidades sofridas por mulheres e pela população LGBTI. Há ainda grupos historicamente discriminados que se caracterizam por carregar uma intersecção natural de vulnerabilidades, como ocorre por exemplo em relação às pessoas em situação de rua.

15. O conceito jurídico de vulnerabilidade não se confunde com o conceito de minoria (noção numérica ou quantitativa de um grupo em relação à sociedade majoritária), hipossuficiência (incapacidade socioeconômica de suprimento das próprias necessidades) ou vitimização (situação decorrente de um dano ou prejuízo efetivo). Por sua vez, a hipervulnerabilidade corresponde à concorrência de mais de um fator de vulnerabilidade experimentado nas mesmas circunstâncias de tempo e espaço.

16. São fundamentos jurídicos gerais da tutela da vulnerabilidade sociocultural: a dignidade da pessoa humana (art. 1º, inc. III, CF/1988), a cláusula constitucional de antidiscriminação (art. $3^{\circ}$, inc. IV, $\mathrm{CF} / 1988$ ), o Direito Internacional dos Direitos Humanos e as 100 regras de Brasília sobre Acesso à Justiça das Pessoas em Condição de Vulnerabilidade.

17. Para que se possa cogitar de um processo justo, síntese epistemológica do direito fundamental à tutela jurisdicional, necessário que o processo civil atenda a ambas as reivindicações contemporâneas por justiça, oferecendo não apenas remédios redistributivos como forma de adequado tratamento da vulnerabilidade socioeconômica, mas também remédios inclusivos como forma de adequado tratamento da vulnerabilidade sociocultural.

18. No paradigma democrático e multicultural, o processo civil deve cercar-se dos instrumentos e garantias necessárias para assumir, sempre que a realidade assim impuser, uma perspectiva procedimental contramajoritária, impedindo que a técnica processual se coloque a serviço da 
exclusão, da estigmatização ou do desrespeito à diferença. Sintetizando: os grupos vulneráveis têm direito à igualdade procedimental quando a diferença os inferioriza e à diferenciação procedimental quando a igualdade os descaracteriza.

19. O processo de cunho social, que se propõe a compensar os déficits de igualdade material entre as partes, revela-se insuficiente ao adequado tratamento dos conflitos que mantém em seu âmago questões identitárias ou pretensões ligadas a discriminações histórico-culturais. Essa constatação denuncia não apenas as limitações da socialização processual para o enfrentamento dos processos de exclusão decorrentes das relações de subordinação e risco social, mas também a necessidade de se repensar o formalismo e a técnica processual a partir destes "novos problemas". Necessário, portanto, que o processo civil considere, ao lado das vulnerabilidades socioeconômicas, as vulnerabilidades socioculturais presentes nos casos concretos, evitando que a noção de igualdade opere sob a premissa da anulação da diferença.

20. A consideração da vulnerabilidade sociocultural não configura um compromisso meramente ético ou político do processo civil, uma vez que, por encontrar-se inserido no paradigma constitucional (art. $1^{\circ}, \mathrm{CPC} / 2015$ ), a disciplina processual deve migrar do plano axiológico para o plano deontológico a partir da concretização de princípios, regras e postulados estabelecidos na Constituição Federal de 1988, dentre os quais é possível destacar o respeito à dignidade humana, a promoção da cidadania, a construção de uma sociedade livre, justa e igualitária e o combate ao preconceito e à discriminação, assim como a proteção dos direitos humanos decorrentes de tratados internacionais ratificados pelo Brasil (art. 13, CPC/2015). Por questão de coerência metodológica, portanto, o processo civil deve concretizar ações, políticas, remédios e apoios em prol de segmentos vulneráveis da população.

21. Como novas exigências por justiça derivada da consideração da vulnerabilidade sociocultural pelo processo, possível elencar: i) a necessidade de um processo civil não discriminatório, vedando-se a reprodução do hate speech processual e a emissão de críticas morais ou juízos de valor sobre o "modo de ser" ou sobre o "projeto de vida" de pessoas em condição de vulnerabilidade; ii) a necessidade de um processo civil que respeite à diferença, garantindo-se a adequada identificação do sujeito vulnerável carente de proteção; iii) a necessidade de um processo civil inclusivo, voltado a facilitar o acesso à justiça de segmentos vulneráveis, seja mediante a adaptação de remédios processuais específicos, seja mediante a remoção de obstáculos administrativos ou judiciários indevidos; iv) a necessidade de um 
processo civil que valorize a autonomia individual, a liberdade de escolha e a participação de sujeitos vulneráveis.

22. "Ações processuais afirmativas" ou "discriminações processuais positivas" são instrumentos voltados a conferir adequado tratamento à vulnerabilidade no processo. Estas medidas se desenvolvem em dois planos: a) legislativo, que envolve a formulação de procedimentos e remédios processuais in abstrato; b) jurisdicional, que permite a adequação procedimental frente às situações de vulnerabilidade concretamente apresentadas. Possível cogitar ainda de ações afirmativas processuais redistributivas, tendo por objeto medidas e apoios voltados a renivelar desigualdades de natureza socioeconômica, e de ações afirmativas processuais inclusivas, tendo por escopo o enaltecimento da diversidade e a particularização da diferença.

23. A tutela jurisdicional humanista ergue-se enquanto premissa à adequação da tutela jurisdicional em favor de indivíduos e grupos vulneráveis, eis que, ao centrar suas preocupações na tutela de pessoas e não na tutela de direitos subjetivos abstratos, permite um repensar do formalismo processual, projetando novos rumos procedimentais ao adequado acesso à justiça de populações marginalizadas.

24. São fundamentos normativos da adequação da tutela jurisdicional em favor de indivíduos vulneráveis, a garantia fundamental de inafastabilidade de jurisdição (art. $5^{\circ}$, inc. XXXV), a proteção e a promoção da dignidade da pessoa humana (art. $1^{\circ}$, inc. III, CF/1988; art. $8^{\circ}$, CPC/2015), a cláusula constitucional de antidiscriminação (art. $3^{\circ}$, inc. IV), os mandamentos de flexibilização contidos nos tratados internacionais de direitos humanos e as 100 Regras de Brasília sobre Acesso à Justiça das Pessoas em condição de Vulnerabilidade.

25. Relevante que o procedimento permita a avaliação concreta pelo magistrado da condição vulnerável suscitada pela parte, condição de possibilidade para a adaptação da técnica processual às situações de fragilidade sociocultural. Consubstanciam nortes à atividade de avaliação concreta da vulnerabilidade no processo pelo magistrado as regras 1.3 e 1.4 das 100 Regras de Brasília e a cláusula-geral de avaliação judicial da vulnerabilidade incluída no parágrafo único do artigo 190 do Código Processual de 2015. Constituem ainda vetores metodológicos voltados a subsidiar a atividade jurisdicional de adequação da técnica processual em favor de indivíduos vulneráveis os princípios: a) pro persona, o qual assegura prioridade à 
norma mais favorável, diante de situações de antinomia normativa ou entrecruzamento de vulnerabilidades; b) favor vulnerabilis, que impõe o favorecimento da parte vulnerável como premissa à flexibilização das regras processuais; c) da adaptação razoável, o qual visa incentivar uma acomodação razoável dos interesses de grupos vulneráveis na flexibilização das normas processuais, amenizando o impacto desproporcional que a adaptação cega pode surtir em relação a grupos não hegemônicos; d) in dubio pro vulnerabilis, que impõe um favorecimento hermenêutico do sujeito vulnerável, diante de várias interpretações possíveis das regras processuais; e) da proteção integral, o qual visa garantir um tratamento integrado das situações peculiares de fragilização e risco social; f) da não fruição obrigatória da ação afirmativa, o qual assegura a excepcionalidade da adequação jurisdicional e a valorização da autonomia da vontade da parte vulnerável, a qual não está obrigada ao desfrute de nenhuma medida afirmativa processual.

26. No que toca à sistematização das principais ações afirmativas processuais contidas nas legislações protetivas, curial apontar: i) a adaptação do procedimento consensual de resolução de conflitos a partir das regras 43 e 44 das 100 Regras de Brasília; ii) a adoção da jurisdição mais favorável (forum shopping) com base no artigo 15 da Lei Maria da Penha; iii) o suprimento do pressuposto processual da capacidade postulatória com base nos artigos 12, §1º 19 e 27 da Lei Maria da Penha, 87 da Lei Brasileira de Inclusão, 49, inciso IV, da Lei no 12.594/2012 e regras 33 e 34 das 100 Regras de Brasília; iv) a garantia de assistência jurídica integral e gratuita prestada pela Defensoria Pública com fulcro nas regras 28, 29 e 30 das 100 Regras de Brasília; v) a extensão da intervenção de terceiro in favor vulnerabilis instituída no artigo 206 do Estatuto da Criança e do Adolescente; vi) a extensão da tramitação prioritária de autos com fulcro no artigo 1.048 do Código Processual de 2015, 71 do Estatuto do Idoso, 152, §1º do Estatuto da Criança e do Adolescente e 33 da Lei Maria da Penha; vii) a concentração de atos processuais e a valorização da oralidade com supedâneo nas regras 35 e 69 das 100 Regras de Brasília; viii) a ampliação das hipóteses de segredo de justiça com base no artigo 143 do Estatuto da Criança e do Adolescente e na regra 76 das 100 Regras de Brasília; ix) a autorização do processamento nas férias forenses e a prática de atos em horários noturnos com suporte no artigo 14, parágrafo único, da Lei Maria da Penha; x) a flexibilização dos prazos processuais com fulcro no artigo 198, inciso II, do Estatuto da Criança e do Adolescente; xi) o conhecimento de pedidos de medidas protetivas de urgência deduzidos por sujeitos vulneráveis com base nos artigos 98 a 102 do Estatuto da Criança e do Adolescente, 43 a 45 do Estatuto do Idoso, 18 a 23 da Lei Maria da Penha, 10, parágrafo único, da Lei Brasileira de Inclusão e $4^{\circ}$ da Lei Nacional de 
Migração; xii) o apoio de equipes multidisciplinares com supedâneo nas regras 41, 64 e 65 das 100 Regras de Brasília, 29 a 32 da Lei Maria da Penha, 150 e 151 do Estatuto da Criança e do Adolescente e $2^{\circ}, \S 1^{\circ}, 4^{\circ}$, inciso I, e $36, \S 1^{\circ}$, da Lei Brasileira de Inclusão; xiii) a extensão das especificidades recursais previstas nos artigos 198 a 199-E do Estatuto da Criança e do Adolescente a outros grupos vulneráveis.

27. No que tange à sistematização das hipóteses de flexibilização do procedimento e adaptação das técnicas processuais inseridas no Código Processual de 2015, relevante mencionar: i) o combate ao hate speech processual com base no princípio da boa-fé objetiva (arts. $5^{\circ}, 77,78 \mathrm{e}$ 80 ); ii) a valorização da autonomia, do direito à informação e da participação com fulcro nos princípios da cooperação e do contraditório (arts. $6^{\circ}, 9^{\circ}$ e 10); iii) a flexibilização das regras de competência territorial (arts. 47 e 53); iv) a realização de atos jurisdicionais em locais diversos do fórum (art. 751); v) a intimação pessoal da parte, excepcionando a regra da citação epistolar (art. 247); vi) a comunicação processual por via eletrônica (arts. 193 a 195); vii) a adaptação de prazos processuais (art. 139, inc. VI); viii) o controle das convenções processuais em razão da vulnerabilidade (art. 190, par. ún.); ix) o respeito ao nome social em demandas envolvendo identidade de gênero e a flexibilização da regra de qualificação da petição inicial em casos de pessoas em situação de rua ou abrigo (art. 319); x) a dispensa do ônus da impugnação específica dos fatos (art. 341); xi) a não aplicação dos efeitos da revelia em caso de ausência justificada e a possibilidade de complementação extemporânea da defesa; xii) a distribuição dinâmica do ônus da prova (art. 373); xiii) o controle difuso de convencionalidade de sentenças internas contrários às decisões da Corte Interamericana de Direitos Humanos; xiv) a aplicação de medidas executivas atípicas na tutela do crédito de sujeitos vulneráveis (arts. 139, inc. IV, 297 e 536, 537 e 538); xv) a dispensa de caução para levantamento de depósito e para a concessão de efeito suspensivo aos embargos à execução; xvi) a adaptação do procedimento especial de "interdição", em respeito aos direitos da pessoa com deficiência; xvii) a flexibilização da obrigatoriedade da sessão consensual no procedimento especial de família em caso de pessoas em situação de violência; xviii) a utilização da técnica de distinção (distinguishing) como garantia do direito à diversidade; xix) a utilização da técnica de superação (overruling) como garantia de revisão de precedentes contrários aos direitos humanos de grupos vulneráveis (arts. 489, §1 $\left.{ }^{\circ}, \mathrm{VI}\right)$; xx) a ampliação da participação de grupos vulneráveis na formação dos precedentes judiciais, por meio da adaptação das regras envolvendo a admissão do amicus curiae e a participação de interessados no incidente de demandas repetitivas (arts. 138, 983 e 984). 
28. A proposta de um microssistema processual protetivo calha à promoção de uma tutela jurisdicional adequada às pessoas em condição de vulnerabilidade sociocultural. Juridicamente, o microssistema se fundamentaria na indivisibilidade e interdependência dos direitos humanos, nas 100 Regras de Brasília sobre Acesso à Justiça das Pessoas em Condição de Vulnerabilidade, assim como no artigo 13 da Lei Maria da Penha, o qual prevê norma expressa de reenvio em relação às regras do Estatuto do Idoso e do Estatuto da Criança e do Adolescente, garantindo a intercomunicabilidade das regras protetivas. 


\section{REFERÊNCIAS}

ABBOUD, Georges; OLIVEIRA, Rafael Tomaz de. O dito e o não-dito sobre a instrumentalidade do processo: críticas e projeções a partir de uma exploração hermenêutica da teoria processual. Revista de Processo, São Paulo, v. 166, dez./2008.

ABREU, Rafael Sirangelo de. A igualdade e os negócios processuais. In: CABRAL, Antonio do Passo; NOGUEIRA, Pedro Henrique (coord.). Coleção grandes temas do novo CPC. Negócios processuais. 3. ed. Salvador: Juspodivm, 2017.

Igualdade e processo: posições processuais equilibradas e unidade do direito.

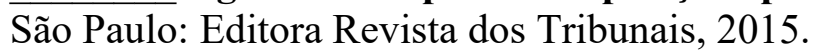

ALENCAR, Rosmar Antonni Rodrigues Cavalcanti de. Comentários ao art. 71 e parágrafos da Lei 10.714/2003. In: PINHEIRO, Naide Maria (coord.). Estatuto do idoso comentado. 4. ed. Campinas: Servandas, 2008.

ALLORIO, Enrico. Problemas de derecho procesal. Tomo 2. Trad. Santiago Sentis Melendo. Buenos Aires: Ediciones Juridicas Europa-America, 1963.

ALMEIDA, Gregório Assagra de. Direito processual coletivo brasileiro: um novo ramo do direito processual. São Paulo: Saraiva, 2003.

ALMEIDA, Gustavo Milaré. O incidente de resolução de demandas repetitivas e o trato de litigiosidade coletiva. In: DIDIER JR., Fredie; MACÊDO, Lucas Buril de; PEIXOTO, Ravi; FREIRE, Alexandre. Coleção Novo CPC doutrina selecionada. Processo nos Tribunais e meios de impugnação às decisões judiciais. Salvador: Juspodivm, 2016, p. 301-315.

AMARAL, Guilherme Rizzo. Cumprimento e execução de sentença sob a ótica do formalismo-valorativo. Porto Alegre: Livraria do Advogado, 2008.

ANDOLINA, Italo; VIGNEIRA, Giuseppe. Il modelo costituzionale del processo civile italiano. Torino: Giappichelli, 1990.

ARAGÃO, Egas Moniz de. Estudo sobre a efetividade do processo de execução. Revista de Processo. São Paulo: Revista dos Tribunais, n. 72, 1993.

ARAÚJO, Fabíola Souza. Mulheres indígenas e salário-maternidade: a colonialidade das decisões judiciais. Dissertação de Mestrado. Faculdade de Direito, Universidade de Brasília, 2016.

ARISTÓTELES, Ética a Nicômaco. Trad. Leonel Vallandro e Gerd Bornheim. São Paulo: Abril Cultural, 1973.

ARMELIN, Donaldo. Tutela jurisdicional diferenciada. Revista de Processo. São Paulo: Editora Revista dos Tribunais, ${ }^{\circ} 65$.

AROCA, Juan Montero. El proceso civil en el siglo XXI: tutela y garantia, Revista del Instituto Colombiano de Derecho Procesal, Bogotá, v. 32, n. 32, 2006. 
La prueba en el proceso civil. 6. ed. Espanha: Thomson Reuters, 2011;

ASSIS, Araken de. Direito comparado e a eficiência do sistema judiciário. Revista do Advogado, n. 43, p. 9-25, jun. 1994.

ÁVILA, Humberto. O que é “devido processo legal”? In: DIDIER JR., Fredie (org.). Leituras complementares de processo civil. $9^{\mathrm{a}}$ e. Salvador: Juspodivm, 2011.

AZEVEDO, Júlio Camargo de. A atuação da Defensoria Pública em favor de vulneráveis: proposta de um perfil institucional à luz da função promocional dos direitos humanos. Congresso Nacional de Defensores Públicos (15-17 nov. 2017: Santa Catarina). Livro de teses e práticas exitosas - Defensoria Pública: em defesa das pessoas em situação de vulnerabilidade, p. $95-105$.

A jurisdição e a ação no CPC/2015: um olhar renovado sobre as categorias fundamentais do processo civil. In: SILVA, Franklyn Roger Alves. O CPC 2015 e a perspectiva da Defensoria Pública. 2. ed. Salvador: Editora Juspodivm, 2019, p. 69-82.

O microssistema de Processo Coletivo Brasileiro: Uma Análise feita à luz das Tendências Codificadoras, Revista Jurídica da Escola Superior do Ministério Público do Estado de São Paulo, v. 2, 2012.

Prática cível para Defensoria Pública. Belo Horizonte: Editora CEI, 2018.

- Representatividade Adequada: pressuposto processual específico das Ações Coletivas Brasileiras, Revista Eletrônica de Direito Processual, Rio de Janeiro: Ano 6, Vol. $\mathrm{X}, 2012$.

BARBI, Celso Agrícola. Comentários ao Código de Processo Civil. Vol. 01. 8. ed. Rio de Janeiro: Forense, 1993.

BARBOZA, Heloisa Helena. Vulnerabilidade e cuidado: aspectos jurídicos. In: PEREIRA, TÂNIA da; OLIVEIRA, Guilherme de (Coords.). Cuidado e vulnerabilidade. São Paulo: Atlas, 2009.

BARCELLOS, Ana Paula de. A eficácia jurídica dos princípios constitucionais. O princípio da dignidade da pessoa humana. Rio de Janeiro: Renovar, 2002.

BARREIROS, Lorena Miranda Santos. Convenções processuais e poder público. Salvador: Juspodivm, 2017.

BARREIROS, Lorena Miranda Santos. Estruturação de um sistema de precedentes no Brasil e concretização da igualdade: desafios no contexto de uma sociedade multicultural. In: DIDIER JR., Fredie; CUNHA, Leonardo Carneiro da; ATAÍDE JR., Jaldemiro Rodrigues de; MACÊDO, Lucas Buril de. Precedentes. Coleção grandes temas do Novo CPC. Vol. 3. 2. ed. Salvador: Juspodivm, 2016.

BARROSO, Luís Roberto. Interpretação e aplicação da constituição. 3. ed. São Paulo: Saraiva, 1999.

. Temas de Direito Constitucional. Vol. III. Rio de Janeiro: Renovar, 2008. 
BECK, Ulrich. Sociedade de risco - rumo a uma outra modernidade. São Paulo: Editora 34, 2011.

BECKER, Laércio Alexandre. Contratos Bancários - execuções especiais. São Paulo: Malheiros Editores, 2002.

BECKER, Laércio. O mito da neutralidade do juiz. Disponível em: http://egov.ufsc.br/portal /sites/default/files/anexos/16673-16674-1-PB.htm. Acesso em: 22 de outubro de 2018.

BEDAQUE, José Roberto dos Santos. Direito e processo - influência do direito material sobre o processo. 6 e. São Paulo: Malheiros, 2011.

. Efetividade do processo e técnica processual. 2. ed. São Paulo: Malheiros, 2007.

Tutela cautelar e tutela antecipada: tutelas sumárias e de urgência (tentativa de sistematização). 3. ed. São Paulo: Malheiros Editores, 2003.

BENOIT (F. P.). Notions et concepts, instruments de la connaissance juridique. Les leçons de la "Philosophie du droit" de Hegel. In: GALBERT (J.M.), TERCINET (M.R.). Mélanges en l'honneur du Professeur Gustave Peiser. Grenoble, PUG, 1995.

BERIZONCE, Roberto Omar. Ideologías y proceso. In: Processo em Jornadas. LUCON, Paulo Henrique dos Santos; AGRIPLIANO, Ricardo de Carvalho et. al. (coord.). Salvador: JusPodivm, 2016.

BIANCHINI, Alice. Lei Maria da Penha. Lei $n^{0}$ 11.340/2006: aspectos assistenciais, protetivos e criminais da violência de gênero. São Paulo: Saraiva, 2013.

BLONDEL, Marion. La personne vulnérable en droit international. Droit. Université de Bordeaux, 2015.

BOBBIO, Norberto. A era dos direitos. Rio de Janeiro: Elsevier, 2004.

BOECKEL, Fabrício Dani de. Tutela jurisdicional do direito a alimentos. Porto Alegre: Livraria do Advogado, 2007.

BONAVIDES, Paulo. Teoria constitucional da democracia participativa. 2. ed. São Paulo: Malheiros, 2003.

BRAGA, Paulo Sarna. Norma de processo e norma de procedimento: o problema da repartição de competência legislativa no Direito Constitucional brasileiro. Salvador: Juspodivm, 2015.

BUCCI, Maria Paula Dallari. Fundamentos para uma teoria jurídica das políticas públicas. São Paulo: Saraiva, 2013.

BUENO, Cassio Scarpinella. Curso sistematizado de Direito Processual Civil. Vol. 1. 8. ed. São Paulo: Saraiva, 2014.

. Manual de direito processual civil. 3. ed. São Paulo: Revista dos Tribunais, 2017. 
. Manual de direito processual civil: inteiramente estruturado à luz do novo CPC - Lei n. 13.105, de 16-3-2015. São Paulo: Saraiva, 2015.

. Novo Código de Processo Civil anotado. São Paulo: Saraiva, 2015.

BÜLOW, Oskar von. La teoria de las excepciones procesales y los presupuestos procesales. Trad. Miguel Angel Rosa Lichtstein. Buenos Aires: Ejea, 1964.

BUSTAMANTE, Thomas da Rosa de. Teoria do precedente judicial - a justificação e a aplicação de regras jurisprudenciais. São Paulo: Noeses, 2012.

BUTLER, Judith. Problemas de gênero - feminismo e subversão da identidade. 8. ed. São Paulo: Saraiva, 2015.

CABRAL, Antonio do Passo. A duração razoável do processo e a gestão do tempo no novo Código de Processo Civil. In: DIDIER JR., Fredie (org.). Normas Fundamentais. Coleção grandes temas do Novo CPC, Vol. 8. Salvador: Juspodivm, 2016.

A escolha da causa-piloto nos incidentes de resolução de processos repetitivos. Revista de Processo, São Paulo, vol. 231, maio/2014.

. Despolarização do processo e "zonas de interesse": sobre a migração entre polos da demanda. In: DIDIER JR., Fredie; MOUTA, José Henrique; MAZZEI, Rodrigo. Tutela jurisdicional coletiva. $2^{\mathrm{a}}$ série. Salvador: Editora Juspodivm, 2012.

. O novo procedimento-modelo (Musterverfahren) alemão: uma alternativa às ações coletivas, Revista de Processo, São Paulo, v. 32, n. 147, p. 123-146, maio/2007.

. Pelas asas de Hermes: a intervenção do amicus curiae, um terceiro especial, Revista de Processo, São Paulo, v. 29, n. 117, p. 9-41, set./out. 2004.

Convenções processuais. 2. ed. Salvador: Juspodivm, 2018.

CALAMANDREI, Piero. Instituciones de derecho procesal civil. Trad. Santiago Sentís Melendo. Buenos Aires: Ediciones Jurídicas Europa América, 1986.

. Introduccion al estúdio sistematico de las providencias cautelares. Trad. Santiago Sentis Melendo. Buenos Aires: Editorial Bibliografica Argentina, 1945.

CÂMARA, Alexandre Freitas. Lições de direito processual civil. Vol. 1. Rio de Janeiro: Lumen juris, 2004.

CAMARGO, Solano de. Forum shopping: modo lícito de escolha da jurisdição? Dissertação de Mestrado. Faculdade de Direito da Universidade de São Paulo, São Paulo, 2015.

CAMBI, Eduardo. A prova civil: admissibilidade e relevância. São Paulo: Revista dos Tribunais, 2006.

Neoconstitucionalismo e neoprocessualismo - direitos fundamentais, políticas públicas e protagonismo judiciário. São Paulo: Almedina, 2016. 
CANOTILHO, José Joaquim Gomes. Constituição dirigente e vinculação do legislador. Contributo para a compreensão das normas constitucionais programáticas. 2. ed. Coimbra: Coimbra Editora, 2001.

. Direito Constitucional e teoria da Constituição. 7. ed. Coimbra: Almedina, 2003.

CANTEROS, Fermín. Estructura básica de los discursos garantista y activista del derecho procesal. Rosário: Juris, 2012

CAPOTORTI, Francesco. Minority Rights: internacional standarts and guidance for implementation. ONU.E/CN.4/Sub.2/384/Rev.1,§568. Disponível em: https://www.ohchr.org/Documents /Publications/MinorityRights_en.pdf. Acesso em 18 de outubro de 2018.

CAPPELlETTI, Mauro. Processo, Ideologias e Sociedade. Vol. 1. Trad. Elício de Cresci Sobrinho. Porto Alegre: Sergio Antonio Fabris Editor, 2008

Processo, ideologias e sociedade. Vol. II. Trad. Hermes Zanetti Jr. Porto Alegre: Sergio Antonio Fabris Editores, 2010.

CAPPELLETTI, Mauro; GARTH, Bryant. Acesso à justiça. Trad. Ellen Gracie Northfleet. Porto Alegre: Sergio Antonio Fabris Editor. 1988.

CARNEIRO, Paulo Cézar Pinheiro. O Ministério Público no processo civil e penal. Rio de Janeiro: Forense, 6. ed., 2001.

CARNELUTTI, Francesco. Derecho y processo. Trad. Santiago Sentis Melendo. Buenos Aires: Ediciones Jurídicas Europa-América, 1971.

. Diritto e processo. Nápoles: Morano, 1953-1958, n. 232.

Sistema di diritto processuale civile. Vol. I. Padova: CEDAM, 1936.

CASTRO, Daniel Penteado de. Considerações sobre a sobrevivência dos procedimentos especiais no NCPC. In: DIDIER JR., Fredie; MACÊDO, Lucas Buril de; PEIXOTO, Ravi; FREIRE, Alexandre (coord.). In: Coleção Novo CPC Doutrina Selecionada. Procedimentos especiais, tutela provisória e direito transitório. 2. ed. Salvador: Juspodivm, 2016.

CAVALCANTI, Marcos. Incidente de resolução de demandas repetitivas e ações coletivas. Salvador: Juspodivm, 2015.

CHASE, Oscar G. Direito, cultura e ritual. Trad. Sérgio Cruz Arenhart e Gustavo Osna. São Paulo: Marcial Pons, 2014.

CHIAVARIO, Mario. Processo e garanzie della persona. 2. ed. Milano: Giuffrè Editore, 1982.

CHIOVENDA, Giuseppe. Instituições de direito processual civil. Vol. 1. São Paulo: Saraiva, 1969.

Instituições de direito processual civil. Vol. 2. Trad. J. Guimarães Menegale. São Paulo: Saraiva, 1965. 
Instituições de direito processual civil. Vol. 3. Trad. J. Guimarães Menegale. São Paulo: Saraiva, 1965.

. Principii di diritto processuale civile. Napoli, Jovene, 1980.

CINTRA, Antonio Carlos de Araújo; GRINOVER, Ada Pellegrini; DINAMARCO, Cândido Rangel. Teoria geral do processo. $31^{\mathrm{a}}$ e. São Paulo: Malheiros Editores, 2015.

COMOGLIO, Luigi Paolo. Il giusto processo nella dimensione comparatística. Rivista di diritto processuale 3, v. 57, 2002.

COMOGLIO, Luigi Paolo; FERRI, Corrado. La tutela cautelare in Italia: profili sistematici e riscontri comparativi. Rivista di diritto processuale. Padova: CEDAM, 1990.

COMOGLIO, Luigi Paolo; FERRI, Corrado; TARUFFO, Michele. Lezioni sul processo civile. Vol I. 4. ed. Bologna: Il Mulino, 2006.

CONCI, Luiz Guilherme Arcaro; GERBER, Konstantin; PEREIRA, Giovanna de Mello Cardoso. Normas ius cogens e princípio pro persona. In: MAIA, Luciano Mariz; LIRA, Yulgan. Controle de convencionalidade - temas aprofundados. Salvador: Juspodivm, 2018.

COSTA, Eduardo José da Fonseca. Levando a imparcialidade a sério: proposta de um modelo interseccional entre Direito Processual, Economia e Piscologia. Salvador: Juspodivm, 2018.

. O direito vivo das liminares. São Paulo: Saraiva, 2011.

COUTURE, Eduardo J. Fundamentos des derecho procesal civil. 4. ed. Montevideo: Bdef Editorial, 2010.

. Proyecto de Código de Procedimiento Civil. Montevideo: Impressora Uruguaya,

CRUZ, José Raimundo Gomes da. Estudos sobre o processo e a constituição de 1988. São Paulo: Editora Revista dos Tribunais, 1993.

CUNHA, Leonardo Carneiro da; NETO, João Luiz Lessa. Mediação e conciliação no Poder Judiciário e o Novo Código de Processo Civil. In: DIDIER JR., Fredie; MACEDO, Lucas Buril de; PEIXOTO, Ravi; FREIRE, Alexandre (coord.). In: Coleção Novo CPC Doutrina Selecionada - Parte Geral. 2. ed. Salvador: Juspodivm, 2016.

CUNHA, Rogério Sanches; PINTO, Ronaldo Batista. Violência doméstica. Lei Maria da Penha comentada artigo por artigo. 5. ed. São Paulo: Revista dos Tribunais, 2014.

DEGENKOLB. Einlassungszwang und Urteilsnorm. Beiträge zur materiellen Theorie der Klagen, insbesondereder Anerkennungsklagen. Leipzig: Druck und Verlag von Breitkopf und Härtel, 1877.

DELFINO, Lúcio. Como construir uma interpretação garantista do processo jurisdicional? Revista Brasileira de Direito Processual - RBDPro, Belo Horizonte, ano 25, n. 98, abr./jun. 2017. 
DESCOLA, Philippe. Outras naturezas, outras culturas. Trad. Cecilia Ciscato. São Paulo: Editora 34, 2016.

DI MAJO, Adolfo. La tutela civile dei diritti. Milano: Giuffrè, 1993.

DIAS. Maria Berenice. A Lei Maria da Penha na justiça. 3. ed. São Paulo: Editora Revista dos Tribunais, 2012.

DIDIER Jr., Fredie Souza. Sobre dois importantes, e esquecidos, princípios do processo: adequação e adaptabilidade do procedimento. Revista de Direito Processual Civil, Gênesis, Curitiba, n. 21, 2001.

. Curso de Direito Processual Civil. Vol. 1. 20ª e. Salvador: Juspodivm, 2018.

. Os três modelos de direito processual: inquisitivo, dispositivo e cooperativo.

Revista de Processo, v. 36, n. 198, p. 213-225, ago./2011.

Princípio do respeito ao autorregramento da vontade no processo civil. CABRAL, Antonio do Passo; NOGUEIRA, Pedro Henrique (coord.). In: Negócios processuais. Coleção grandes temas do novo CPC. 3. ed. Salvador: Juspodivm, 2017.

2018.

. Sobre a teoria geral do processo, essa desconhecida. 4. ed. Salvador: Juspodivm,

DIDIER JR., Fredie; NOGUEIRA, Pedro Henrique Pedrosa. Teoria dos fatos jurídicos processuais. 2. ed. Salvador: Juspodivm, 2013.

DIDIER JR., Fredie; OLIVEIRA, Rafael Alexandria de. A Lei Maria da Penha e o novo CPC. In: COSTA, Eduardo Fonseca da; SICA, Heitor Vitor Mendonça. Legislação processual extravagante. Salvador: Editora Juspodivm, 2016.

DIDIER JR., Fredie Souza; ZANETI JR., Hermes. Justiça Multiportas e tutela jurisdicional adequada. In: DIDIER JR., Fredie et. al. (coord.). Justiça Multiportas. Mediação, conciliação, arbitragem e outros meios de solução adequada de conflitos. Coleção grandes temas do NCPC. Salvador: Juspodivm, 2017.

DINAMARCO, Cândido Rangel. A instrumentalidade do processo civil. 8. ed. São Paulo: Malheiros, 2000.

Execução civil. 4. ed. São Paulo: Malheiros, 1994.

Fundamentos do Processo Civil Moderno. Tomo I. 6. ed. São Paulo: Malheiros Editores, 2010.

. Instituições de Direito Processual Civil. Vol. I. 8. ed. São Paulo: Malheiros, 2016.

Editores. 2017.

. Instituições de Direito Processual Civil, Vol. II. 7. ed. São Paulo: Malheiros

. Instituições de Direito Processual Civil, Vol. III. 7. ed. São Paulo: Malheiros Editores, 2017. 
. Instituições de Direito Processual Civil. Vol. IV. 3. ed. São Paulo: Malheiros, 2009.

. Litisconsórcio. 8. ed. São Paulo: Malheiros Editores, 2009.

DUARTE, Clarice Seixas. Fundamentos filosóficos da proteção à minoria. In: JUBILUT, Liliana Lyra; BAHIA, Alexandre Gustavo Melo Franco. MAGALHÃES, José Luiz Quadros de (coord). Direito à diferença - aspectos teóricos e conceituais da proteção às minorias e aos grupos vulneráveis, Vol. 1. São Paulo: Saraiva, 2013.

DURKHEIM, Émile. Da divisão social do trabalho. Trad. Eduardo Brandão. 2. ed. São Paulo: Editora Martins Fontes, 1999.

DUXBURY, Neil. The nature and the autority of precedents. Cambridge University Press: Cambridge, 2007.

DWORKIN, Ronald. A virtude soberana: a teoria e a prática da igualdade. Trad. Jussara Simões. São Paulo: Martins Fontes, 2005.

. Levando os direitos a sério. Trad. Nelson Boeira. 3. ed. São Paulo: Editora WMF Martins Fontes, 2010.

ESTEVES, Diogo; ALVES SILVA, Franklyn Roger. Princípios Institucionais da Defensoria Pública. $2^{\mathrm{a}}$ ed. Rio de Janeiro: Forense, 2017.

FABRÍCIO, Adroaldo Furtado. Adequação dos prazos como forma de adaptar procedimentos: ação de prestação de contas, Revista de Processo, São Paulo, vol. 197, p. 414-444, jul./2011.

FALLON JR., Richard. Stare decisis ante the Constitution: na essay on constitutional methodology. New York University Review, n. 76, 2001.

FARBER, Daniel A. The Rule of Law and the Law of Precedents. 90 Minnesotta Law Review, $1.173,2005$.

FAUNDEZ, Julio. Non state Justice Systems in Latin America. Case Studies: Peru and Colombia, University of Warwick, 2003. Disponível em: http://siteresources.worldbank.org/INTJUSFORPOOR/Resources/NonStateJusticeSystemsinL atinAmerica.pdf. Acesso em: 30/10/2018.

FAZZALARI, Elio. Diffusione del processo e compiti dela dottrina. Rivista Trimestrale di Diritto e Procedura Civile. Milano: Giuffrè, n. 3, 1958.

. Instituzioni di Diritto Processuale. 8. ed. Padova: CEDAM, 1996.

. Note in tema di diritto e processo. Milano: Giuffrè, 1957.

. Procedimento e processo (teoria generale). In: Enciclopedia del diritto. Milano: Giuffrè, 1986.

FERES JR., João; POGREBINSCHI, Thamy. Teoria Política Contemporânea: uma introdução. Rio de Janeiro: Elsevier, 2010. 
FERNANDES, Valéria Diez Scarance. Lei Maria da Penha - o processo penal no caminho da efetividade: abordagem jurídica e multidisciplinar. São Paulo: Atlas, 2015.

FERRAZ JR., Tércio Sampaio. Função social da dogmática jurídica. 2. ed. São Paulo: Atlas, 2015.

FIECHTER-BOULVARD, Frédérique. La notion de vulnerabilité et as consécration par le droit. In: COHET-CORDEY, Frédérique (org.). Vulnérabilité et le droit: le developpement de la vulnérabilité et ses enjeux en droit. Grenoble: Presses Universitaires de Grenoble, 2000.

FIGUEIRA JR., Joel Dias. O princípio constitucional da igualdade em confronto com a lei que confere tratamento processual privilegiado aos idosos; análise da constitucionalidade da Lei 10.173, de 09/01/2002, Revista de Processo, São Paulo, v. 27, n. 106, p. 294, abr./jun., 2002.

FISS, Owen. Um novo processo civil: estudos norte-americanos sobre jurisdição, constituição e sociedade. São Paulo: Revista dos Tribunais, 2004.

FONSÊCA, Vitor. Processo civil e direitos humanos. São Paulo: Thomsom Reuters Brasil, 2018.

FRANCO, Glauce; MAGNO, Patrícia. I Relatório de atuação em prol de pessoas e/ou grupos em condição de vulnerabilidade. Brasília: ANADEP, 2015.

FRASER, Nancy; HONNETH, Axel. Redistribution or recognition? A political philosophical exchange. New York: Verso, 2003.

FUX, Luiz. Tutela da segurança e tutela da evidência. São Paulo: Saraiva, 1996.

GADAMER, Hans-George. Verdade e Método. Trad. Flávio Paulo Meurer. Petrópolis: Vozes, 1997.

GAJARDONI, Fernando da Fonseca. Flexibilização procedimental - um novo enfoque para o estudo do procedimento em matéria processual. São Paulo: Atlas, 2008.

. Os procedimentos simplificados e flexibilizados no Novo CPC. In: DIDIER JR., Fredie; MACÊDO, Lucas Buril de; PEIXOTO, Ravi; FREIRE, Alexandre (coord.). Coleção Novo CPC Doutrina Selecionada. Parte Geral. 2. ed. Salvador: Juspodivm, 2016

. Técnicas de aceleração do processo. Franca: Lemos \& Cruz, 2003

GALANTER, Marc. Why the "haves" come out ahead: speculations on the limits of legal change. Law and society review, Vol. 4, 1974.

GALINDO, BRUNO. O direito antidiscriminatório entre a forma e a substância: igualdade material e proteção de grupos vulneráveis pelo reconhecimento da diferença. In: FERRAZ, Carolina Valença; LEITE, Glauber Salomão (coord.). Direito à diversidade. São Paulo: Atlas, 2015.

GARGARELlA, Roberto. As teorias da justiça depois de Rawls. Um breve manual de filosofia política. 2. ed. São Paulo: WMF Martins Fontes, 2008.

GIDDENS, Anthony. A constituição da sociedade. 2. ed. São Paulo: Martins Fontes, 2003. 
GODINHO, Robson Renault. A proteção processual dos direitos dos idosos. Rio de Janeiro: Editora Lumen Juris, 2010.

. Negócios processuais sobre o ônus da prova no novo Código de Processo Civil. São Paulo: Revista dos Tribunais, 2015.

. O Ministério Público como substituto processual no processo civil. Rio de Janeiro: Lumen Juris, 2007.

. Tutela jurisdicional diferenciada e técnica processual. In: CIANCI, Mirna; QUARTIERI, Rita de Cassia Rocha Conte; MOURÃO, Luiz Eduardo; GIANNICO, Ana Paula Chiovitti (coord.). Temas atuais de tutelas diferenciadas. Estudos em homenagem ao Professor Donaldo Armelin. São Paulo: Saraiva, 2009.

GOLDSCHMIDT, James. Principios generales del processo. Buenos Aires: EJEA, 1961.

GOMES JR., Luiz Manoel. Curso de Direito Processual Civil Coletivo. Rio de Janeiro: Forense, 2005.

GOMES, Joaquim Benedito Barbosa. Ação afirmativa e principio da igualdade - o direito como instrumento de transformação social: a experiência dos EUA. Rio de Janeiro: Renovar, 2001.

GRECO, Leonardo. Novas perspectivas da efetividade e do garantismo processual. In: SOUZA, Marcia Cristina Xavier de; RODRIGUES, Walter dos Santos (coord.). O novo Código de Processo Civil: o projeto do CPC e o desafio das garantias fundamentais. Rio de Janeiro: Forense, 2003.

Os atos de disposição processual: primeiras reflexões, Revista Eletrônica de Direito Processual, Rio de Janeiro: UERJ, ano 1, Vol. 1, out-dez, 2007

GRINOVER, Ada Pellegrini et. al. Código Brasileiro de Defesa do Consumidor comentado pelos autores do Anteprojeto. 3. ed. Rio de Janeiro: Forense, 1993.

As garantias constitucionais do direito de ação. São Paulo: Editora Revista dos Tribunais, 1973.

Cumprimento da sentença. In: RENAULT, Sérgio Rabello Tamm; BOTTINI, Pierpaolo Cruz (coord.). A nova execução de títulos judiciais - comentários à Lei 11.232/05. São Paulo: Saraiva, 2006.

Revisitando a teoria geral do processo. In: LUCON, Paulo Henrique dos Santos; AGRIPLIANO, Ricardo de Carvalho et. al (coord.). Processo em Jornadas. Salvador: Juspodivm, 2016.

GROSTEIN, Julio. O papel da Defensoria Pública na mutação constitucional: um enfoque à luz das atribuições institucionais. In: RÉ, Aluísio Iunes Monti Ruggeri; SOARES DOS REIS, Gustavo Augusto (coords.). Temas aprofundados da Defensoria Pública. Vol. 2. Salvador: Juspodivm, Salvador, 2014.

GUANDALINI JR., Walter. O sentido do teu mundo. In: JUBILUT, Liliana Lyra; BAHIA, Alexandre Gustavo Melo Franco. MAGALHÃES, José Luiz Quadros de (coord). Direito à 
diferença - aspectos teóricos e conceituais da proteção às minorias e aos grupos vulneráveis, Vol. 1. São Paulo: Saraiva, 2013.

GUEDES, Cintia Regina. O incidente de resolução de demandas repetitivas e o papel da defensoria pública como porta voz dos direitos dos litigantes individuais na formação da tese jurídica vinculante. XIII Congresso Nacional de Defensores Públicos Santa Catarina, 2017. Disponível em: https://www.anadep.org.br/wtksite/cms/conteudo/38642/CINTIA REGINA_GUEDES.pdf. Acesso em: 02/11/2018.

HÄBERLE, Peter. Hermenêutica Constitucional - a Sociedade Aberta dos Intérpretes da Constituição. Trad. Gilmar Ferreira Mendes. Porto Alegre: Sérgio Antônio Fabris editor, 1997.

HABERMAS, Jürgen. A inclusão do outro - estudos de teoria política. 2. ed. São Paulo: Loyola, 2004.

. Consciência moral e agir comunicativo. Rio de Janeiro: Tempo Brasileiro, 1989.

. Direito e democracia: Entre facticidade e validade. $2^{\mathrm{a}}$ ed. Rio de Janeiro: Tempo Brasileiro, 2003, v. 1 e 2.

O discurso filosófico da modernidade: doze lições. São Paulo: Martins Fontes, 2002.

Técnica e ciência como ideologia. Lisboa: Edições 70, 1987.

HENDERSON, Humberto. Los tratados internacionales de derechos humanos em el orden interno: la importância del principio pro homine, Revista do Instituto Interamericano de Derechos Humanos, n. 39, Costa Rica, 2004.

HERRERA FLORES, Joaquín. La reinvención de los derechos humanos. Madrid: Atrapasueños, 2005.

HERTEL, Daniel Roberto. Técnica processual e tutela jurisdicional: a instrumentalidade substancial das formas. Porto Alegre: Sérgio Antonio Fabris Editora, 2006.

HESS, Konrad. A Força Normativa da Constituição. Trad. de Gilmar Ferreira Mendes. Porto Alegre: Sérgio Antônio Fabris Editor, 1991.

HONNETH, Axel. Luta por reconhecimento: a gramática moral dos conflitos sociais. Trad. Luiz Repa. 2. ed. São Paulo: Editora 34, 2009.

JOBIM, Marco Félix. As funções da eficiência no processo civil brasileiro. São Paulo: Thomson Reuters Brasil, 2018.

Cultura, escolas e fases metodológicas do processo. Porto Alegre: Livraria do

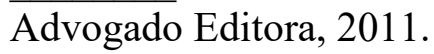

JUBILUT, Liliana Lyra. Itinerários para a proteção das minorias e dos grupos vulneráveis: os desafios conceituais e de estratégias de abordagem. In: JUBILUT, Liliana Lyra; BAHIA, Alexandre Gustavo Melo Franco; MAGALHÃES, José Luiz Quadros de (coord.). Direito à diferença: aspectos teóricos e conceituais da proteção às minorias e aos grupos vulneráveis. Vol. 1. São Paulo: Saraiva, 2013. 
JUNQUEIRA, Gustavo; REIS, Gustavo Augusto Soares dos; ZVEIBEL; Daniel Guimarães. Comentários à Lei da Defensoria Pública. São Paulo: Saraiva, 2013.

KAFKA, Franz. O Processo. Trad. Modesto Carone. São Paulo: Martin Claret, 2002.

KYMLICKA, Will. Multicultural citizenship: a liberal theory of minority rights. Oxford: Oxford University Press, 1995.

KYMLICKA, Will. Para além da dicotomia indígena/minoria? In: JUBILUT, Liliana Lyra; BAHIA, Alexandre Gustavo Melo Franco; MAGALHÃES, José Luiz Quadros de (org.). Direito à diferença: aspectos teóricos e conceituais da proteção às minorias e aos grupos vulneráveis. Vol. 2. São Paulo: Saraiva, 2013.

LACERDA, Galeno. Comentários ao Código de Processo Civil. 7. ed. Rio de Janeiro: Forense. 1998. Vol. 8. t. I, p. 23.

O Código como sistema legal de adequação do processo, Revista do Instituto dos Advogados do Rio Grande do Sul, Porto Alegre, 1976.

. Processo e cultura, Revista de Direito Processual Civil, São Paulo, Saraiva, v. 3, 1961.

LEAL, André Cordeiro. Instrumentalidade do processo em crise. Belo Horizonte: Mandamentos, 2008.

LEAL, Rosemiro Pereira. Teoria geral do processo: primeiros estudos. $9^{\mathrm{a}}$ e. Rio de Janeiro: Forense, 2010.

LEONEL, Ricardo de Barros. Tutela jurisdicional diferenciada. São Paulo: Revista dos Tribunais, 2010.

LIEBMAN, Enrico Tullio. Manual de direito processual. Vol I. Trad. e notas de Cândido Rangel Dinamarco. Rio de Janeiro: Forense, 2005.

LIMA, Clarissa Costa de. O tratamento do superendividamento e o direito de recomeçar dos consumidores. São Paulo: Editora Revista dos Tribunais, 2014.

LIMA, Fausto Rodrigues de. Da atuação do Ministério Público - artigos 25 e 26. In: CAMPOS, Carmen Hein de (org.). Lei Maria da Penha: comentada em uma perspectiva jurídicofeminista. Rio de Janeiro: Lumen juris, 2011.

LOPES DA COSTA, Alfredo Araújo. Medidas preventivas. 2. ed. Belo Horizonte: Bernardo Álvares, n. 53, 1958.

LOPES, Ana Maria D’ávilla. Tolerar para coexistir, dialogar para conviver: desafios do multiculturalismo. In: JUBILUT, Liliana Lyra; BAHIA, Alexandre Gustavo Melo Franco; MAGALHÃES, José Luiz Quadros de (coord.). Direito à diferença: aspectos teóricos e conceituais da proteção às minorias e aos grupos vulneráveis. Vol. 1. São Paulo: Saraiva, 2013.

MACCORMICK, Neil; SUMMERS, Robert S. Interpreting precedents: a comparative study. Aldershot: Ashgate, 1997. 
MACÊDO, Lucas Buril de. Precedentes judiciais e o direito processual civil. 2. ed. Salvador: Juspodivm, 2017.

. Reclamação fundada em precedentes obrigatórios no CPC/2015. In: DIDIER JR., Fredie; org. MACÊDO, Lucas Buril de; PEIXOTO, Ravi; FREIRE, Alexandre (coord.). Coleção Novo CPC doutrina selecionada. Processo nos Tribunais e meios de impugnação às decisões judiciais. Salvador: Juspodivm, 2016.

MACÊDO, Lucas Buril de; PEIXOTO, Ravi Medeiros. Ônus da prova e sua dinamização. 2. ed. Salvador: Juspodivm, 2016.

MAIA, Maurilio Casas. A intervenção de terceiro da Defensoria Pública nas ações possessórias multitudinárias do NCPC: colisão de interesses (art. 4º-A, V, LC n. 80/1994) e posições processuais dinâmicas. In: DIDIER JR., Fredie; MACÊDO, Lucas Buril de; PEIXOTO, Ravi; FREIRE, Alexandre (coord.). Coleção Novo CPC Doutrina Selecionada - Parte Geral. 2. ed. Salvador: Juspodivm, 2016.

MANCUSO, Rodolfo de Camargo. A resolução dos conflitos e a função judicial no contemporâneo Estado de Direito. 2. ed. São Paulo: Editora Revista dos Tribunais, 2014.

Acesso à justiça: condicionantes legítimas e ilegítimas. 2. ed. São Paulo: Editora Revista dos Tribunais, 2015.

Incidente de Resolução de Demandas Repetitivas - a luta contra a dispersão jurisprudencial excessiva. São Paulo: Revista dos Tribunais, 2016.

. Jurisdição coletiva e coisa julgada. Teoria geral das ações coletivas. 2. ed. São Paulo: Editora Revista dos Tribunais, 2007.

Tribunais, 2015.

Recurso extraordinário e recurso especial. 13. ed. São Paulo: Revista dos

Sistema brasileiro de precedentes: natureza, eficácia e operacionalidade. 2 . ed. São Paulo: Revista dos Tribunais, 2016.

. Teoria geral do processo. Rio de Janeiro: Forense, 2018.

MANDRIOLI, Crisanto. Corso di diritto processuale civile. Vol. I. $11^{\mathrm{a}}$ e. Torino: Giappichelli.

MARCATO, Antonio Carlos. O processo monitório brasileiro. São Paulo: Malheiros Editores, 1998.

. Procedimentos especiais. 17. ed. São Paulo: Atlas, 2017.

MARINONI, Luiz Guilherme. A antecipação da tutela. 10. ed. São Paulo: Revista dos Tribunais.

Incidente de Resolução de Demandas Repetitivas: decisão de questão idêntica

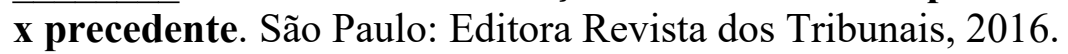

Precedentes obrigatórios. 4. ed. São Paulo: Revista dos Tribunais, 2015. 
Técnica processual e tutela dos direitos. 4. ed. São Paulo: Revista dos Tribunais, 2013.

Tribunais, 2012.

Tutela Inibitória: individual e coletiva. 5. ed. São Paulo: Editora Revista dos

MARINONI, Luiz Guilherme; ARENHART, Sérgio Cruz; MITIDIERO, Daniel. Novo Curso de Processo Civil. Vol. 1. São Paulo: Editora Revista dos Tribunais, 2015.

MARINONI, Luiz Guilherme; ARENHART, Sérgio Cruz; MITIDIERO, Daniel. Novo Curso de Processo Civil. Vol. 2. São Paulo: Editora Revista dos Tribunais, 2015.

MARQUES, Cláudia Lima. Comentários ao artigo $6^{\circ}$. In: MARQUES, Cláudia Lima; BENJAMIN, Antonio Herman V.; MIRAGEM, Bruno. Comentários ao Código de Defesa do Consumidor. 4. ed. São Paulo: Revista dos Tribunais, 2013.

. Sugestões para uma lei sobre o tratamento do superendividamento de pessoas físicas em contratos de crédito ao consumo: proposições com base em pesquisa empírica de 100 casos no Rio Grande do Sul. In: MARQUES, Claudia Lima; CAVALLAZZI, Rosangela Lunardelli (coord.). Direitos do consumidor endividado: superendividamento e crédito. São Paulo: Editora Revista dos Tribunais, 2006.

MARQUES, José Frederico. Instituições. Vol. 1. São Paulo: Forense, 1958.

MARTINEZ, Fernando Rey. La discriminación multiple, une realidade antigua, um conpeto nuevo, Revista española de derecho constitucional, $\mathrm{n}^{\circ}$ 84, Madrid, Centro de Estudios Políticos y Constitucionales, 2008.

MARTINS COSTA, Judith. A "guerra" do vestibular e a distinção entre publicidade enganosa e clandestina, Revista de Direito do Consumidor, São Paulo, n. 6, p. 219-231, abr/jun, 1993.

MARTINS, José de Souza. Exclusão social e a nova desigualdade. São Paulo: Paulus, 1997

MATTOS, Patrícia de Castro. A sociologia política do reconhecimento. As contribuições de Charles Taylor, Axel Honneth e Nancy Fraser. São Paulo: Annablume, 2006.

MAZZILI, Hugo Nigro. A Defesa dos Interesses Difusos em Juízo. 29. ed. São Paulo: Saraiva, 2016.

MEDAUAR, Odete. A processualidade no Direito Administrativo. São Paulo: Revista dos Tribunais, 1993.

MELLO, Patrícia Perrone Campos. Precedentes. O desenvolvimento judicial do direito no constitucionalismo contemporâneo. Rio de Janeiro: Renovar, 2008.

MENEZES, Paulo Lucena de. Ação afirmativa (affirmative action) no direito norteamericano. São Paulo: Revista dos Tribunais, 2001.

MESQUITA, José Ignácio Botelho de. Da ação civil. São Paulo: Editora Revista dos Tribunais, 1975. 
MEYER-PFLUG, Samantha Ribeiro. Liberdade de expressão e discurso do ódio. São Paulo: Editora Revista dos Tribunais, 2009.

MICHAELIS. Moderno dicionário da língua portuguesa. São Paulo: Companhia Melhoramentos, 1998.

MIRAGEM, Bruno. Curso de Direito do Consumidor. 3. ed. São Paulo: RT, 2012.

MIRAGEM, Bruno. Direito à diferença e autonomia: proteção da diversidade no direito privado em relação ao exercício individual das liberdades sexual e religiosa. In: FERRAZ, Carolina Valença; LEITE, Glauber Salomão (coord.). Direito à diversidade. São Paulo: Atlas, 2015.

MIRAGEM, Bruno; MARQUES, Cláudia Lima. O novo direito privado e a proteção dos vulneráveis. 2. ed. São Paulo: Editora Revista dos Tribunais, 2014.

MIRANDA, Francisco Cavalcanti Pontes de. Comentários ao Código de Processo Civil. Tomos 8 e 12. Rio de Janeiro: Forense, 1976.

. Tratado das Ações. Tomo I. São Paulo: Revista dos Tribunais, 1970.

MITIDIERO, Daniel. Colaboração no processo civil: pressupostos sociais, lógicos e éticos. 2. ed. São Paulo: Editora Revista dos Tribunais, 2011.

Tendências em matéria de tutela sumária: da tutela cautelar à técnica

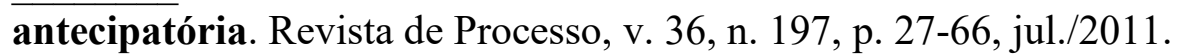

MOLINARO, Carlos Alberto. Dignidade, interculturalidade e direitos humanos e fundamentais - uma nova tecnologia? In: BERTOLDI, Márcia Rodrigues; GASTAL, Alexandre Fagundes; CARDOSO, Simone Tassinari (org.). Direitos Fundamentais e vulnerabilidade social: em homenagem ao professor Ingo Wolfgang Sarlet. Porto Alegre: Livraria do Advogado, 2016.

MONTESQUIEU. Do espírito das leis. São Paulo: Abril cultural, 1973.

MORAES, Maria Celina Bodin de. O princípio da dignidade da pessoa humana. In: MORAES, Maria Celina Bodin de (coord.). Na medida da pessoa humana. Estudos de direito civilconstitucional. Rio de Janeiro: Renovar, 2010.

MORAES, Paulo Valério Dal Pai. Código de Defesa do Consumidor: o princípio da vulnerabilidade no contrato, na publicidade, nas demais práticas comerciais. 3 . ed. Porto Alegre: Livraria do Advogado, 2009.

MOREIRA, José Carlos Barbosa. Antecipação de tutela: algumas questões controvertidas. In: Temas de direito processual. $8^{\text {a }}$ série. São Paulo: Saraiva, 2004.

Convenções das partes sobre matéria processual. In: Temas de direito processual. $\mathbf{3}^{\text {a }}$ Série. São Paulo: Saraiva, 1994.

. Efetividade do processo e técnica processual. In: Temas de Direito Processual. $6^{\mathbf{a}}$ série. São Paulo: Saraiva, 1997.

Eficácia da sentença de interdição por alienação mental. In: Temas de Direito Processual. $4^{a}$ série. São Paulo: Saraiva, 1995. 
- Notas sobre o problema da efetividade do processo. In: Temas de Direito Processual. $3^{\text {a }}$ Série. São Paulo: Saraiva, 1994.

. O futuro da justiça: alguns mitos. In: Temas de direito processual: $\mathbf{8}^{\mathbf{a}}$ série. Rio de Janeiro: Forense, 2004.

MOREIRA, Adilson José. O mito da inocência branca no debate brasileira sobre ações afirmativas. JUBILUT, Liliana Lyra; BAHIA, Alexandre Gustavo Melo Franco; MAGALHÃES, José Luiz Quadros de (org.). In: Direito à diferença: aspectos teóricos e conceituais da proteção às minorias e aos grupos vulneráveis. Vol. 2. São Paulo: Saraiva, 2013.

NAGAO, Paulo Issamu. O papel do juiz na efetividade do Processo Civil contemporâneo. São Paulo: Malheiros, 2016.

NERY JR., Nelson. Princípios do processo na Constituição Federal. 10. ed. São Paulo: Revista dos Tribunais, 2009.

NETO, José Mario Wanderley Gomes; VEIGA, Ana Carolina Gomes. Crítica aos dispositivos processuais contidos no Estatuto do Idoso: um estudo de caso frente ao acesso à justiça. Revista de Processo, v. 143, 2007.

NEVES, Daniel Amorim Assumpção. Manual de direito processual civil. 10. ed. Salvador: Juspodivm, 2018.

NEVES, Marcelo. Direitos humanos: inclusão ou reconhecimento. In: FERRAZ, Carolina Valença; LEITE, Glauber Salomão (coord.). Direito à diversidade. São Paulo: Atlas, 2015.

NOGUEIRA, Pedro Henrique Pedrosa. Negócios jurídicos processuais. 2. ed. Salvador: Juspodivm, 2017.

NUNES, Dierle José Coelho. Processo jurisdicional democrático. Curitiba: Juruá, 2012.

NUNES, Luiz Antônio Rizzato. Curso de direito do consumidor. 4. ed., São Paulo: Saraiva, 2009.

OLIVEIRA JR., José Alcebíades de. Diversidade cultural e a efetivação dos direitos humanos. In: FERRAZ, Carolina Valença; LEITE, Glauber Salomão (coord.). Direito à diversidade. São Paulo: Atlas, 2015.

OLIVEIRA JR., Zulmar Duarte et. al. Teoria geral do processo: comentários ao CPC de 2015 - parte geral. São Paulo: Forense, 2015.

OLIVEIRA, Carlos Alberto Alvaro de. Do formalismo no processo civil - proposta de um formalismo-valorativo. 3. ed. São Paulo: Saraiva, 2009.

. Efetividade e processo de conhecimento, Revista de Processo, São Paulo, Revista dos Tribunais, v. 36, 1999. 
Efetividade e tutela jurisdicional. In: MACHADO, Fábio Cardoso; AMARAL, Guilherme Rizzo (coord.). Polêmica sobre a ação - a tutela jurisdicional na perspectiva das relações entre direito e processo. Porto Alegre: Livraria do Advogado, 2006.

. Os direitos fundamentais à efetividade e à segurança em perspectiva dinâmica, Revista de Processo, v. 33, n. 155, p. 11-26, jan. 2008.

. Teoria e prática da tutela jurisdicional. São Paulo: Forense, 2008.

OSNA, Gustavo. Processo civil, cultura e proporcionalidade: análise crítica da teoria processual. São Paulo: Editora Revista dos Tribunais, 2017.

OTEIZA, Eduardo. Punto de vista: MARC/ADR y diversidade de culturas: el ejemplo latinoamericano. In: ZANETI JR., Hermes; CABRAL, Trícia Navarro Xavier (coord.). Justiça Multiportas. Col. Grandes Temas do Novo CPC. Salvador: Juspodivm, 2017.

PAIVA, Caio Cezar. Prática Penal para Defensoria Pública. Rio de Janeiro: Forense, 2016.

PASSOS, José Joaquim Calmon de. Direito, poder, justiça e processo: julgando os que nos julgam. Rio de Janeiro: Forense, 2000.

Ensaios e artigos. Vol. II. DIDIER JR., Fredie; BRAGA, Paula Sarno (org.). Col. Obras de J. J. Calmon de Passos. Vol. 2. Salvador: Juspodivm, 2016.

Esboço de uma teoria das nulidades aplicada às nulidades processuais. Rio de Janeiro: Forense, 2002.

Instrumentalidade do processo e devido processo legal. In: FIUZA, César Augusto de Castro; SÁ, Maria de Fátima Freire; DIAS Ronaldo Brêtas de Carvalho (coord.). Temas atuais de Direito Processual Civil. Belo Horizonte: Del Rey, 2001.

PEIXOTO, Ravi. Superação do precedente e segurança jurídica. 2. ed. Salvador: Juspodivm, 2016.

PERONI, Lourdes; TIMMER, Alexandra. Vulnerable groups: The promise of an emerging concept in European Human Rights Convention law, International Journal of Constitutional $\boldsymbol{L} \boldsymbol{a} \boldsymbol{w}$, vol. 11, n 4, Oxford University Press and New York University School of law, 2013.

PETERS, Michael. Pós-estruturalismo e filosofia da diferença. Belo Horizonte: Autêntica, 2000.

PEYRANO, Jorge W. Aspectos procesales de la responsabilidade professional. In: MORELLO, Augusto M. et. al. (coord.). Lãs Responsabilidades Profesionales - Libro al Dr. Luis O. Andorno. La Plata: LEP, 1992.

La doctrina de las cargas probatorias dinámicas puesta a prueba, Revista uruguaya de derecho procesal, n. 2, 1992.

PICARDI, Nicola. Manuale del processo civile. Milano: Giuffrè, 2006.

PINTO, Monica. El principio pro homine. Criterios de hermenêutica y pautas para la representación de lós derechos humanos. In: La aplicación de lós tratados de derechos 
humanos por lós tribunales locales. Buenos Aires: Ediar, Centro de Estudios Legales y Sociales - Editorial del Puerto, 1997.

PINTO, Ronaldo Batista. Violência doméstica. Lei Maria da Penha comentada artigo por artigo. 5. ed. São Paulo: Revista dos Tribunais, 2014.

PIOVESAN, Flávia. Proteção dos direitos humanos sob as perspectivas de raça, etnia, gênero e orientação sexual. Perspectivas do constitucionalismo brasileiro à luz dos sistemas global e regional de proteção. In: BERTOLDI, Márcia Rodrigues; GASTAL, Alexandre Fagundes; CARDOSO, Simone Tassinari (org.). Direitos Fundamentais e vulnerabilidade social: em homenagem ao professor Ingo Wolfgang Sarlet. Porto Alegre: Livraria do Advogado, 2016.

PISANI, Andréa Proto. Breve premessa a um corso sulla Giustizia Civile. Appunti sulla giustizia civile. Bari: Carucci, 1982.

Brevi note in tema di tutela specifica e tutela risarcitoria. Foro Italiano, 1983.

L'effetività dei mezzi di tutela giurisdizionale com particolare riferimento all'attuazione dela sentenza di condanna. Rivista di diritto processuale, 1975.

Nuovi diritti e tecniche di tutela. In: Scritti in onore di Elio Fazzalari. Vol. 2. Milano: Giuffrè, 1993.

Problemi dela c. d. tutela giurisdizionale diferenziata. Appunti sulla giustizia civile. Bari: Caccuci, 1982.

Sulla tutela giurisdizionale differenziata. Rivista di diritto processuale. Padova: $\overline{\text { CEDAM, }} \mathrm{n}^{\circ}$ 4, 1979.

Tutela giurisdizionale differenziata e nuovo processo del lavoro. Studi di diritto processuale del lavoro. Milano: Giuffrè, 1977.

PLÓSZ, Alexander. Beiträge zur Theorie des Klagerechts. Leipzig: Duncker \& Humblot, 1880.

QUEIROZ, M.P.M. Diversidade e desigualdade: guia de estudos. Lavras: UFLA, 2010.

RAATZ, Igor. Autonomia privada e processo civil: negócios jurídicos processuais, flexibilização procedimental e o direito à participação na construção do caso concreto. Salvador: Juspodivm, 2017.

RAMOS, André de Carvalho. Curso de Direitos Humanos. São Paulo: Saraiva, 2014.

RAPISARDA, Cristina. Profili dela tutela civile inibitoria. Padova: Cedam, 1987.

REDONDO, Bruno Garcia. Adequação do procedimento pelo juiz. Salvador: Juspodivm, 2017.

Tutela jurisdicional. Revista de Processo, vol. 187, set. 2010.

RIOS, Roger Raup. Direito da antidiscriminação: discriminação direta, discriminação indireta e ações afirmativas. Porto Alegre: Livraria do Advogado, 2008. 
ROCCO, Alfredo. La sentenza civile. Milano: Giuffrè, 1962.

ROCCO, Ugo. Tratado de derecho procesal civil: processo cautelar. Vol. 5. Buenos Aires: Depalma, 1977.

ROCHA, Cármen Lucia Antunes. Ação afirmativa - o conteúdo democrático do princípio da igualdade, Revista Informação Legislativa, v. 33, n. 131, jul/ste, 1996.

ROSSATO, Luciano Alves; LÉPORE, Paulo Eduardo; CUNHA, Rogério Sanches. Estatuto da Criança e do Adolescente - comentado artigo por artigo. 7. ed. São Paulo: Saraiva, 2015.

SALLES, Carlos Alberto de. Procedimento dotado de normatividade - uma proposta de unificação conceitual. In: 40 anos da teoria geral do processo. ZUFELATO, Camilo; YARSHELL, Flávio Luiz. São Paulo: Malheiros Editores, 2013.

SANTOS, Boaventura de Sousa. Reconhecer para libertar: os caminhos do cosmopolitismo multicultural. 2. ed. Rio de Janeiro: Civilização Brasileira, 2010.

. A construção intercultural da igualdade e da diferença. In: A gramática do tempo: para uma nova cultura política. São Paulo: Cortez, 2010.

. Uma concepção multicultural dos direitos humanos, Revista de Cultura e Política, São Paulo, Lua nova, no 39, 1997.

SANTOS, Welder Queiroz dos. Princípio do contraditório e vedação de decisão surpresa. Rio de Janeiro: Forense, 2018.

SARLET, Ingo Wolfgang. Dignidade da pessoa humana e direitos fundamentais na Constituição Federal de 1988. 6. ed. Porto Alegre: Livraria do Advogado, 2008.

SARMENTO, Daniel. A liberdade de expressão e o problema do hate speech. In: SARMENTO, Daniel. Livres e iguais: estudos de Direito Constitucional. Rio de Janeiro: Lumen Juris, 2006.

Horizonte: Fórum, 2016.

SCHAUER, Frederick. Precedent, Standford Law Review, vol. 39, 1987.

SEMPRINI, Andrea. Multiculturalismo. Trad. Laureano Pelegrin. Bauru: EDUSC, 1999.

SÊNECA. Sobre a brevidade da vida. Trad. William Li. São Paulo: L\&PM.

SHRADER, Elizabeth; SAGOT, Montserrat. Domestic Violence: Women's Way Out. Washington: Pan American Health Organization, 2000. Acesso em 10/11/2018. Disponível em: http://www1.paho.org/english/hdp/hdw/womenswayout.pdf

SICA, Heitor Vitor Mendonça. O direito de defesa no Processo Civil brasileiro. Um estudo sobre a posição do réu. São Paulo: Atlas, 2011.

. Tendências evolutivas da execução civil brasileira. In: ZUFELATO, Camilo; BONATO, Giovanni; SICA, Heitor Vitor Mendonça; CINTRA, Lia Carolina Batista. I Colóquio Brasil-Itália de Direito Processual Civil. Salvador: Juspodivm, 2015. 
. Velhos e novos institutos fundamentais do Direito Processual Civil. In: ZUFELATO, Camilo; YARSHELL, Flávio Luiz. 40 anos da Teoria Geral do Processo no Brasil. São Paulo: Malheiros, 2013.

SILVA, Carlos Augusto. O processo civil como estratégia de poder: reflexo da judicialização da política no Brasil. Rio de Janeiro: Renovar, 2004.

SILVA, Franklyn Roger Alves; ESTEVES, Diogo. A curadoria especial no Novo Código de Processo Civil. In: SOUSA, José Augusto Garcia de (coord.). Defensoria Pública - Col. Repercussões do Novo CPC. Salvador: Juspodivm, 2015.

SILVA, José Afonso da. Aplicabilidade das normas constitucionais. 8. ed. 2. ed. São Paulo: Malheiros Editores, 2015.

Do recurso extraordinário no direito processual brasileiro. São Paulo: Editora Revista dos Tribunais, 1963.

SILVA, Ovídio Araújo Baptista da. Do processo cautelar. 4. ed. Rio de Janeiro: Forense, 2009. . Teoria da ação cautelar. Rio de Janeiro: Forense, 1996;

. Curso de processo civil. Vol. 1. 7. ed. Rio de Janeiro: Forense, 2005.

2006.

. Processo e ideologia: o paradigma racionalista. 2. ed. Rio de Janeiro: Forense,

SIMMEL, Geog. Sociologia. São Paulo: Ática, 1983.

SOARES, Rogério Aguiar Munhoz. Tutela jurisdicional diferenciada. Tutelas de urgência e medidas liminares em geral. São Paulo: Malheiros, 2000.

SOUZA, Jamille Fernanda Ferreira de. Políticas públicas e direitos fundamentais do idoso: abordagem brasileira. In: SIQUEIRA, Dirceu Pereira; SILVA, Nilson Tadeu reis Campos. Minorias \& grupos vulneráveis. Reflexões para uma tutela inclusiva. Birigui/SP: Boreal Editora, 2013.

SOUZA, Sérgio Ricardo. Comentários à lei de combate à violência contra a mulher. 3. ed. Curitiba: Juruá, 2009.

SOWELL, Thomas. Ação afirmativa ao redor do mundo - um estudo empírico sobre cotas e grupos preferenciais. Trad. Joubert de Oliveira Brízida. São Paulo: É Realizações, 2016.

STRECK, Lenio Luis. Hermenêutica jurídica em crise: uma exploração hermenêutica da construção do Direito. 8. ed. Porto Alegre: Livraria do Advogado, 2009.

STRECK, Lenio Luiz; ABBOUD, Georges. O que é isto - o precedente judicial e as súmulas vinculantes? Porto Alegre: Livraria do Advogado, 2013.

TALAMINI, Eduardo. O exame de sentenças da jurisdição brasileira pela Corte Interamericana de Direitos Humanos. In: FABRÍCIO, Adroaldo Furtado (coord.). Meios de impugnação ao julgado civil: estudos em homenagem a José Carlos Barbosa Moreira. Vol. 1. Rio de Janeiro: Forense, 2007. 
Tribunais, 1998.

. Tutela monitória - A ação monitória - Lei 9.079/95. São Paulo: Revista dos

TARELLO, Giovanni. Dottrine del processo civile - studi storici sulla formazione del diritto processuale civile, a cura di R. Guastini e G. Rebuffa. Bologna: Il Mulino, 1989.

TARTUCE, Fernanda. Igualdade e vulnerabilidade no processo civil. Rio de Janeiro: Forense, 2012.

2016.

. Mediação nos conflitos civis. $3^{\mathrm{a}}$ ed. Rio de Janeiro: Forense; São Paulo: Método,

TARUFFO, Michele. Precedente e giurisprudenza, Rivista Trimestrale di Diritto e Procedura Civile, n. 3, set./2007.

Milano, 2009.

Cultura e processo, Rivista Trimestrale di Diritto e Procedura Civile, anno 63,

TARZIA, Giuseppe. Considerazioni conclusive. Les mesures provisoires em procédure civile. Milano: Giuffrè, 1985.

TAYLOR, Charles. Argumentos filosóficos. São Paulo: Edições Loyola, 2000.

$\overline{\text { Loyola, } 1997 .}$

As fontes do self: a construção da identidade moderna. São Paulo: Edições $\overline{\text { Press, } 1992 .}$

. Multiculturalism and the Politics of Recognition. Princeton: Princeton University

TEMER, Sofia. Incidente de resolução de demandas repetitivas. Salvador: Juspodivm, 2016.

TEPEDINO, Gustavo; SCHREIBER, Anderson. Les minorités dans le Droit civil brélisien. In: Travaux de l'Association Henri Capitant: journées Mexicaines. Rapport Bresilien, mai./2002.

THEODORO JR., Humberto. Curso de Direito Processual Civil. Vol. 1. 58. ed. Rio de Janeiro: Forense, 2017.

. Estrutura e função no campo do Direito Processual - visão estática e visão dinâmica do fenômeno jurídico. In: Tutelas diferenciadas como meio de incrementar a efetividade da prestação jurisdicional. THEODORO JR., Humberto; LAUAR, Maira Terra (coord.). Rio de Janeiro: GZ Editora, 2010.

. Processo Cautelar. 25. ed. São Paulo: LEUD, 2010.

. Tutela jurisdicional de urgência. Rio de Janeiro: América Jurídica, 2001.

THEODORO JR., Humberto; NUNES, Dierle; BAHIA, Alexadre Melo Franco; PEDRON, Flávio Quinad. Novo CPC - fundamentos e sistematização. 3. ed. Rio de Janeiro: Forense, 2016.

TOMMASEO, Ferrucio, Appunti di diritto processuale civile. Torino: Giappichelli, 1995. 
TRINDADE, Antônio Augusto Cançado. Tratado de direito internacional dos direitos humanos. Vol. 1. Porto Alegre: Fabris, 1997.

TUCCI, José Rogério Cruz e. Ação monitória. 2. ed. São Paulo: Revista dos Tribunais, 1997.

. Duração razoável do processo (art. 5, LXXVIII, da Constituição Federal). In: JAYME, Fernando Gonzaga; FARIA, Juliana Cordeiro de; LAUAR, Maira Terra (coord.). Processo civil: novas tendências. Estudos em homenagem ao professor Humberto Theodoro Júnior. Belo Horizonte: Del Rey, 2008.

Parâmetros de eficácia e critérios da interpretação do precedente judicial. In: Direito Jurisprudencial. WAMBIER, Teresa Arruda Alvim (coord.). São Paulo: Revista dos Tribunais, 2012.

Precedente judicial como fonte do Direito. São Paulo: RT, 2004.

. Tempo e processo. São Paulo: Revista dos Tribunais, 1997.

TUCCI, José Rogério Cruz e; AZEVEDO, Luiz Carlos de. Lições de processo civil canônico - história e direito vigente. São Paulo: Editora Revista dos Tribunais, 2001.

Tribunais, 2013.

Lições de história do processo civil romano. 2. ed. São Paulo: Editora Revista dos

VENTURI, Elton. Transação de direitos indisponíveis? In: ZANETI JR., Hermes; CABRAL, Trícia Navarro Xavier (coord.). Justiça Multiportas. Col. Grandes Temas do Novo CPC. Salvador: Juspodivm, 2017.

VERNANT, Jean-Pierre. O universo, os deuses, os homens. Trad. Rosa Freire d'Aguiar. São Paulo, Companhia das Letras, 2000.

VIDIGAL, Erick. O novo CPC e a dignidade da pessoa humana: primeiros passos rumos à construção de uma doutrina humanista de Direito Processual Civil. In: FREIRE, Alexandre; DANTAS, Bruno et. al (coord.). Novas tendências do Processo Civil - estudos sobre o Projeto do novo Código de Processo Civil. Vol. I. Salvador: JusPodivm, 2013.

VINCENZI, Brunela Vieira de; REZENDE, Ariadi Sandrini. A mediação como forma de reconhecimento e empoderamento do indivíduo. In: ZANETI JR., Hermes; CABRAL, Trícia Navarro Xavier (coord.). Justiça Multiportas. Col. Grandes Temas do Novo CPC. Salvador: Juspodivm, 2017.

WACH, Adolf. Handbuch des deutshen Civilprozessrechts. Leipzig: Duncker \& Humblot, 1886.

WAMBIER, Luiz Rodrigues; TALAMINI, Eduardo. Curso avançado de processo civil. Vol. 1. 16. ed. São Paulo: RT, 2016.

WAMBIER, Teresa Arruda Alvim. Controle das decisões judiciais por meio de recursos de estrito direito e de ação rescisória - recurso especial, recurso extraordinário e ação rescisória: o que é uma decisão contrária à lei? São Paulo: Revista dos Tribunais, 2001. 
WATANABE, Kazuo. A mentalidade e os meios alternativos de solução de conflitos no Brasil. In: GRINOVER, Ada Pellegrini; NETO, Caetano Lagrasta; WATANABE, Kazuo (coord.). Mediação e Gerenciamento do Processo - revolução na prestação jurisdicional. 3. ed. São Paulo: Atlas, 2013.

. Acesso à justiça e sociedade moderna. In: GRINOVER, Ada Pellegrini et. al. (coord.). Participação e processo. São Paulo: Revista dos Tribunais, 1988.

. Código brasileiro de Direito do Consumidor. Rio de Janeiro, Forense, 1991.

. Cultura da sentença e cultura da pacificação. In: YARSHELL, Flávio Luiz; ZANOIDE, Maurício e Morais (coord.). Estudos em homenagem à professora Ada Pellegrini Grinover. São Paulo: Editora DPJ, 2005.

WINDSCHEID, Bernhard; MUTHER, Theodor. Polemica sobre la “actio". Tradução de Tomás A. Banzhaf. Buenos Aires: Ediciones Jurídicas Europa-América, 1976.

YARSHEL, Flávio Luiz. Convenção das partes em matéria processual: rumo a uma nova era. In: CABRAL, Antonio do Passo; NOGUEIRA, Pedro Henrique (coord.). Coleção grandes temas do novo CPC. Negócios processuais. 3. ed. Salvador: Juspodivm, 2017.

. Tutela jurisdicional específica nas obrigações de declarações de vontade. São Paulo: Malheiros Editores, 1993.

. Tutela jurisdicional. 2. ed. São Paulo: DPF Editora, 2006.

ZANETI JR., Hermes. A constitucionalização do processo. 2. ed. São Paulo: Atlas, 2014.

. O Ministério Público e o Novo processo civil. Salvador: Editora Juspodivm, 2018.

ZAVASKI, Teori Albino. Antecipação da tutela. 6. ed. São Paulo: Saraiva, 2008.

.. Processo coletivo: tutela de direitos coletivos e tutela coletiva de direitos. 6 . ed. São Paulo: Revista dos Tribunais, 2014.

ZENKNER, Marcelo. Ministério Público e efetividade do Processo Civil. São Paulo: Editora Revista dos Tribunais, 2006.

ZUFELATO, Camilo. Flexibilização procedimental e gestão processual no Direito brasileiro. In: ZUFELATO, Camilo; BONATO, Giovanni; SICA, Heitor Vitor Mendonça; CINTRA, Lia Carolina Batista. I Colóquio Brasil-Itália de Direito Processual Civil. Salvador: Juspodivm, 2015.

Precedentes judiciais vinculantes à brasileira no novo CPC: aspectos gerais. In: $\mathbf{O}$ novo Código de Processo Civil - questões controvertidas. São Paulo: Atlas, 2015.

\section{JURISPRUDÊNCIA}


CORTE INTERAMERICANA DE DIREITOS HUMANOS. Caso do Povo Saramaka vs Suriname. Exceções preliminares, mérito, reparações e custas. Sentença de 28 de novembro de 2007. Série C, n. 172.

CORTE INTERAMERICANA DE DIREITOS HUMANOS. Caso Fernández Ortega e outros vs. México. Exceção preliminar, mérito, reparações e custas. Sentença de 30 de agosto de 2010. Série C, n. 215.

CORTE INTERAMERICANA DE DIREITOS HUMANOS. Caso Ximenes Lopes vs. Brasil, sentença de 04 de julho de 2006.

CORTE INTERAMERICANA DE DIREITOS HUMANOS. Rosendo Cantú e outra. Exceção preliminar, mérito, reparações e custas. Sentença de 31 de agosto de 2010. Série C, n. 216.

SUPERIOR TRIBUNAL DE JUSTIÇA. Agravo Regimental 573/MS. Corte especial, Rel. Min. Nancy Andrighi, j. 29.06.2010.

SUPERIOR TRIBUNAL DE JUSTIÇA. Agravo Regimental no Agravo no 899.653-RJ. Rel. Min. Maria Thereza de Assis Moura, j. 24/08/2009.

SUPERIOR TRIBUNAL DE JUSTIÇA. Agravo Regimental no Agravo Regimental no Recurso Especial n 990085-PA. Rel. Min., Francisco Falcão, j. 19.02.2008.

SUPERIOR TRIBUNAL DE JUSTIÇA. Agravo Regimental no Conflito de Competência no 149.964-MS. Rel. Min. Felix Fisher, j. 22.03.2017.

SUPERIOR TRIBUNAL DE JUSTIÇA. Conflito de Competência n⿳0 101.569-PR. Rel. Min. Jorge Mussi, j. 25.08.2010.

SUPERIOR TRIBUNAL DE JUSTIÇA. Conflito de Competência n⿳0 111.130-SC. Rel. Min. Nancy Andrighi, j. 08.09.2010.

SUPERIOR TRIBUNAL DE JUSTIÇA. Conflito de Competência no 56.438-MS. Rel. Min. Félix Fischer, j. 07/08/2006.

SUPERIOR TRIBUNAL DE JUSTIÇA. Habeas Corpus no 294952-SC. Rel. Min. Felix Fischer, j. 07/04/2015.

SUPERIOR TRIBUNAL DE JUSTIÇA. Habeas Corpus n 379.169-MS. Rel. Min. Reynaldo Soares da Fonseca, j. 24.05.2017.

SUPERIOR TRIBUNAL DE JUSTIÇA. Mandado de Segurança n 13.248-DF. Rel. Min. Castro Meira, j. 04.03.2008.

SUPERIOR TRIBUNAL DE JUSTIÇA. Recurso Especial nº 1.550.166-DF. Rel. Min. Marco Aurélio Bellizze, j. 21/11/2017.

SUPERIOR TRIBUNAL DE JUSTIÇA. Recurso Especial no 1475006-MT. Rel. Min. MOURA RIBEIRO, j. 14/10/2014.

SUPERIOR TRIBUNAL DE JUSTIÇA. Recurso Especial n. 931.513-RS. Rel. Min. Herman Benjamin, j. 25.11.2009. 
SUPERIOR TRIBUNAL DE JUSTIÇA. Recurso Especial no 1.145.083-MG. Rel. Min. Antonio Herman Benjamin, j. 27.09.2011.

SUPERIOR TRIBUNAL DE JUSTIÇA. Recurso Especial no 1.548.57-DF. Rel. Min. Luiz Vicente Cernicchiaro, j. 26.05.1998.

SUPERIOR TRIBUNAL DE JUSTIÇA. Recurso Especial $\mathbf{n}^{\mathbf{0}}$ 1.279.586-PR. Rel. Min. Luis Felipe Salomão, j. 03/10/2017.

SUPERIOR TRIBUNAL DE JUSTIÇA. Recurso Especial n 510.229/RJ. Rel. Min. Francisco Falcão, j. 16.11.2004.

SUPERIOR TRIBUNAL DE JUSTIÇA. Recurso Especial n 897682-MS. Rel. Min. Nancy Andrighi, j. 17.05.2007.

SUPERIOR TRIBUNAL DE JUSTIÇA. Recurso Especial n 1.640.040-SP. Rel. Min. Ribeiro Dantas, j. 15.12.2016.

SUPERIOR TRIBUNAL DE JUSTIÇA. Recurso Especial 1.245.744-SP. Rel. Min. Mauro Campbell Marques, j. 28.06.2011.

SUPERIOR TRIBUNAL DE JUSTIÇA. Recurso Especial nº 1419421-GO. Rel. Ministro Luis Felipe Salomão, j. 11/02/2014.

SUPERIOR TRIBUNAL DE JUSTIÇA. Recurso Especial nº 983.250/RJ. Rel. Min. Luiz Fux, j. 22.04.2009.

SUPERIOR TRIBUNAL DE JUSTIÇA. Súmula 140. TERCEIRA SEÇÃO, j. 18/05/1995.

SUPREMO TRIBUNAL FEDERAL. Habeas Corpus nº 82.424-SP. Rel. Min. Moreira Alves, j. 19/3/2004.

SUPREMO TRIBUNAL FEDERAL. Habeas Corpus n. 91.361-SP. Rel. Min. Celso de Mello, j. 23.09.2008.

SUPREMO TRIBUNAL FEDERAL. Recurso Extraordinário n 466.343-SP. Rel. Min. Cézar Peluso, j. 03.12.2008.

TRIBUNAL DE JUSTIÇA DE SÃO PAULO. 2a Câmara de Direito Criminal. Apelação no 0017860-23.2014.8.26.0002. Rel. Des. Alex Zilenovski, j. 13/06/2016.

TRIBUNAL DE JUSTIÇA DE SÃO PAUlO. 2a Câmara de Direito Privado. Agravo no 2094427-96.2016.8.26.0000. Rel. Des. José Carlos Ferreira Alves, j. 13.05.2016. 